\title{
Article \\ Circulating Phylotypes of White Spot Syndrome Virus in Bangladesh and Their Virulence
}

\author{
Mehedi Mahmudul Hasan ${ }^{1,2}$, M. Nazmul Hoque ${ }^{3}{ }^{(0)}$, Firoz Ahmed ${ }^{4}$, Md. Inja-Mamun Haque ${ }^{5}(\mathbb{D}$, \\ Munawar Sultana ${ }^{1, *}$ and M. Anwar Hossain 1,6,* \\ 1 Department of Microbiology, University of Dhaka, Dhaka 1000, Bangladesh; mehedimahmudul@gmail.com \\ 2 Department of Fisheries and Marine Science, Noakhali Science and Technology University, \\ Noakhali 3814, Bangladesh \\ 3 Department of Gynecology, Obstetrics and Reproductive Health, Bangabandhu Sheikh Mujibur Rahman \\ Agricultural University, Gazipur 1706, Bangladesh; nazmul90@bsmrau.edu.bd \\ 4 Department of Microbiology, Noakhali Science and Technology University, Noakhali 3814, Bangladesh; \\ firoz19701016@gmail.com \\ 5 Department of Fisheries, University of Dhaka, Dhaka 1000, Bangladesh; injamamunhaque@du.ac.bd \\ 6 Vice-Chancellor, Jashore University of Science and Technology, Jashore 7408, Bangladesh \\ * Correspondence: munawar@du.ac.bd (M.S.); hossaina@du.ac.bd (M.A.H.)
}

Citation: Hasan, M.M.; Hoque, M.N.; Ahmed, F.; Haque, M.I.-M.; Sultana, M.; Hossain, M.A. Circulating Phylotypes of White Spot Syndrome Virus in Bangladesh and Their Virulence. Microorganisms 2022, 10 , 191. https://doi.org/10.3390/ microorganisms10010191

Academic Editor: Gianfranco Donelli

Received: 28 November 2021

Accepted: 6 January 2022

Published: 16 January 2022

Publisher's Note: MDPI stays neutral with regard to jurisdictional claims in published maps and institutional affiliations.

Copyright: (C) 2022 by the authors. Licensee MDPI, Basel, Switzerland. This article is an open access article distributed under the terms and conditions of the Creative Commons Attribution (CC BY) license (https:// creativecommons.org/licenses/by/ $4.0 /)$.

\begin{abstract}
White Spot Syndrome Virus (WSSV) has emerged as one of the most prevalent and lethal viruses globally and infects both shrimps and crabs in the aquatic environment. This study aimed to investigate the occurrence of WSSV in different ghers of Bangladesh and the virulence of the circulating phylotypes. We collected 360 shrimp (Penaeus monodon) and 120 crab (Scylla sp.) samples from the south-east (Cox's Bazar) and south-west (Satkhira) coastal regions of Bangladesh. The VP28 gene-specific PCR assays and sequencing revealed statistically significant $(p<0.05$, Kruskal-Wallis test) differences in the prevalence of WSSV in shrimps and crabs between the study areas (Cox's Bazar and Satkhira) and over the study periods (2017-2019). The mean Log load of WSSV varied from 8.40 (Cox's Bazar) to 10.48 (Satkhira) per gram of tissue. The mean values for salinity, dissolved oxygen, temperature and $\mathrm{pH}$ were $14.71 \pm 0.76 \mathrm{ppt}, 3.7 \pm 0.1 \mathrm{ppm}, 34.11 \pm 0.38^{\circ} \mathrm{C}$ and $8.23 \pm 0.38$, respectively, in the WSSV-positive ghers. The VP28 gene-based phylogenetic analysis showed an amino-acid substitution $(\mathrm{E} \rightarrow \mathrm{G})$ at the 167th position in the isolates from Cox's Bazar (referred to as phylotype BD2) compared to the globally circulating one (BD1). Shrimp PL artificially challenged with BD1 and BD2 phylotypes with filtrates of tissue containing $0.423 \times 10^{9}$ copies of WSSV per $\mathrm{mL}$ resulted in a median LT50 value of $73 \mathrm{~h}$ and $75 \mathrm{~h}$, respectively. The in vivo trial showed higher mean Log WSSV copies (6.47 \pm 2.07 per mg tissue) in BD1-challenged shrimp PL compared to BD2 ( $4.75 \pm 0.35$ per mg tissue). Crabs infected with BD1 and BD2 showed 100\% mortality within $48 \mathrm{~h}$ and $62 \mathrm{~h}$ of challenge, respectively, with mean Log WSSV copies of $12.06 \pm 0.48$ and $9.95 \pm 0.37$ per gram tissue, respectively. Moreover, shrimp antimicrobial peptides (AMPs), penaeidin and lysozyme expression were lower in the BD1-challenged group compared to BD2 challenged shrimps. These results collectively demonstrated that relative virulence properties of WSSV based on mortality rate, viral load and expression of host immune genes in artificially infected shrimp PL could be affected by single aa substitution in VP28.
\end{abstract}

Keywords: VP28; WSSV; phylotypes; real-time PCR; viral load

\section{Introduction}

Shrimp aquaculture is one of the major earning sources in many countries including Bangladesh and plays a vital role in enlightening community advancement, food security, employment opportunities and poverty reduction [1,2]. In Bangladesh, shrimp aquaculture provides livelihood to around 85 million people (mostly coastal people) and serves as the second most foreign currency-earning source, which contributes about $5 \%$ to national 
GDP [3,4]. Black tiger shrimp (Penaeus monodon) contributes $26 \%$ to the total aquacultural production in Bangladesh, while crabs contribute 6\% [5]. Studies suggested that $P$. monodon can adapt to a wide range of salinity from 4 to $40 \mathrm{ppt}$, dissolved oxygen from 4 to $7 \mathrm{ppm}$, temperature from $25^{\circ} \mathrm{C}$ to $32{ }^{\circ} \mathrm{C}$, and $\mathrm{pH}$ from 7.5 to 9 [6,7]. The mud crab, Scylla spp., is distributed widely throughout the Indo-Pacific region [8]. Recently, mud crab (Scylla olivacea) farming has had an increasing trend in the coastal areas of Bangladesh due to their higher disease resistance capacity and market values [9]. Among the marine crustaceans, crabs are supposed to be less vulnerable to the effects of climate change and deterioration of water quality. To date, more than 98 species have been found as hosts or carriers of WSSV [10], and of them, mud crabs have been considered to be a particularly potential threat to shrimp farms because of their carrier status [10-12]. Moreover, mud crabs may well suppress viral replication by inducing the apoptosis of hemocytes [13].

The WSSV is one of the major threats to the shrimp industry over the past two decades globally. This is a very fast reproducing, wide spreading and highly virulent crustacean pathogen $[14,15]$. Studies have demonstrated the widespread pathogenicity of WSSV among many marine crustaceans, including shrimp, crayfish and crabs $[13,16]$. The outbreak of WSSV depends on the interactions among the pathogen, host and environment [17], and thus, the interaction between WSSV and the hosts have been a research focus in recent years. This virus can be transmitted both horizontally and vertically $[12,18]$, and once an outbreak of WSSV occurs, it wipes out the entire population in many aquatic farms within a few days [14]. Infection of the WSSV in shrimp is characterized by a rapid mortality of up to $100 \%$ within 7-10 days [19]. Up to now, there is no completely efficient method to protect the shrimp from WSSV infection. Appropriate protective management is enormously important for reducing WSSV infections in shrimp farms [20]. In Bangladesh, eggs are hatched in the hatcheries from mother shrimps collected from the Bay of Bengal, and shrimp post larvae (PL) from these hatcheries are distributed throughout the country. PL traders directly catch and sell to shrimp farmers as well. Breeding of the WSSV-resistant types should be the most effective approach towards solving the virus disease problem [15]. However, comprehensive study regarding the physicochemical parameters of ghers (shrimp ponds) of Cox's Bazar and Satkhira districts of Bangladesh, and identification of circulating WSSV in those areas are lacking.

The circular genome of the WSSV is approximately $275 \mathrm{~nm}$ in length and $120 \mathrm{~nm}$ in width with tail-like appendages at one end, and composed of five known major structural proteins: VP28, VP19, VP26, VP24 and VP15 [19,21]. Studies on WSSV viral proteins have demonstrated that VP28 and VP19 are associated with the virion envelope [21,22], while VP26 acts as a tegument protein linking the two nucleocapsid-associated proteins VP24 and VP15 to the envelope $[17,23]$. The VP28 is required for WSSV entry into host cells by endocytosis, cell-to-cell infection and virus propagation [22]. Moreover, this envelop protein plays a significant role in initiating the WSSV infection in shrimp [22]. The VP28 gene of WSSV is suggestively involved in endosome escape through its interaction with the host Rab7 [24], and has been identified as a potent target for dsRNA treatment in comparative studies [25]. Previous analyses of strain variability reported that competitive fitness depends on the size of the genome [26,27]; however, these studies are far from enough to illustrate all the mechanisms of WSSV pathogenesis. The on-going mutations in the structural proteins such as VP28 could explain most phenotypic variance of WSSV for certain traits $[15,28]$. Siddique and colleagues confirmed a mutation at amino acid position 167 of the VP28 gene of WSSV in Bangladesh with glycine instead of glutamic acid on that position [29]. However, the virulence properties of different phylotypes of WSSV remain unknown. Therefore, this study investigated the impact of physicochemical parameters on the prevalence of WSSV, the virulence properties of circulating phylotypes of WSSV based on mortality observation and the viral load count in shrimp PL artificially infected with two circulating phylotypes of WSSV. 


\section{Materials and Methods}

\subsection{Sampling and Measurement of Physicochemical Parameters}

Shrimp (P. monodon) and crab (Scylla sp.) samples were collected from Sadar Upazilla of Cox's Bazar District and 5 Upazillas namely: Satkhira Sadar (SS), Debhata (D), Asassuni (A), Kaliganj (K) and Shyamnagar (S) of the Satkhira District which are situated in the south-east and south-west coastal regions of Bangladesh (Figure 1). Satkhira is situated in the southernmost coastal region of Bangladesh, and approximately $32 \%$ of the area of this district (nearly 66,800 hectors out of 211,000 hectors) consists of shrimp farms and contributes $34 \%(23,400$ metric ton out of 69,000$)$ of the entire shrimp production. Cox's Bazar is situated in the south-east coastal region of Bangladesh where most of the shrimp hatcheries are situated and approximately 41,594 ha is under shrimp and crab aquaculture [5]. In this study, samples were collected from 20 ghers during the period when farmers reported the presence of WSD in the area (five from Cox's Bazar and fifteen from Satkhira). A total of 360 shrimps and 120 crabs were grossly collected after farmers complained of the death of the crustaceans in their farming ghers (shrimp ponds) during monsoon season (May-June) in 2017 to 2019. We also continued our sampling in postmonsoon season (October) during the three-year study period (2017-2019) when no death of crustaceans reported in the study ghers by the respective farmers. Data on temperature, $\mathrm{pH}$, dissolved oxygen and salinity were collected from the study ghers.

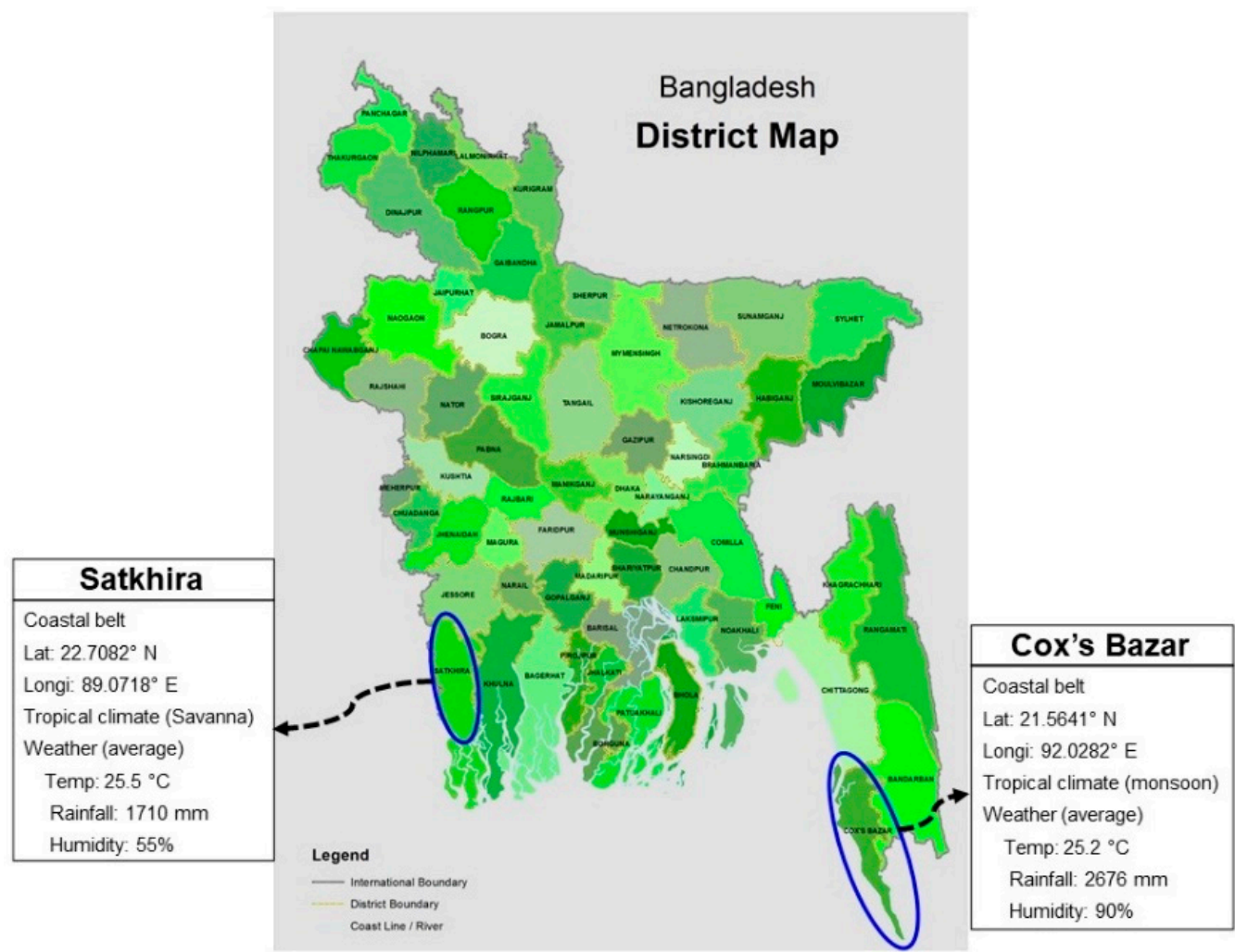

Figure 1. South-east and south-west coastal regions of Bangladesh (marked using blue colour) where shrimp ghers are located.

\subsection{DNA Extraction}

After initial screening considering symptoms of disease, tissue DNA was extracted from the collected samples (from both shrimp and crabs) by an automated DNA extraction system (MaxWell 16 ${ }^{\circledR}$ Tissue DNA Purification kit; AS 1030, Promega, Madison, WI, USA), according to manufacturer's instruction [29]. In addition, DNA was also extracted from artificially challenged shrimp PL tissues. For this, challenged shrimp PL tissue were collected in sterile $1.5 \mathrm{~mL}$ microfuge tubes and mashed into fine particles with a glass rod 
prior to DNA extraction. DNA concentration and purity were measured by Nano-Drop 2000 (Thermo Scientific, Waltham, MA, USA) [20].

\subsection{Conventional and Quantitative Real-Time PCR ( $q P C R)$ Assay}

The extracted DNA underwent conventional PCR assay for the amplification of VP28 gene using GoTaq $2 \times$ Hot Start Colorless Master Mix (Promega, Madison, WI, USA) with forward and reverse primers [29,30]. The conventional PCR reactions included denaturation at $95{ }^{\circ} \mathrm{C}$ for $50 \mathrm{~min}$, annealing at $55^{\circ} \mathrm{C}$ for $30 \mathrm{~s}$, extension at $72{ }^{\circ} \mathrm{C}$ for $45 \mathrm{~s}$, and repeated for 30 cycles with a final extension of $5 \mathrm{~min}$ at $72{ }^{\circ} \mathrm{C}$. We used $1.0 \%$ agarose gel (with ethidium bromide staining) in TAE buffer to separate and visualize the PCR-amplified products. Following electrophoresis, the bands were photographed under UV light (Figure S1A).

The real-time qPCR was performed with primer pair WSSV-q28F $5^{\prime}$-TGTGACCAAG ACCATCGAAA-3' and WSSV-q28R 5'-CTTGATTTTGCCCAAGGTGT-3' following previously developed methods [29] with a few adjustments. In the current study, recombinant plasmid-based standard was used instead of the purified PCR product-based standard $[29,31]$. The recombinant plasmid that contained the VP28 gene (TOPO TA Vector with complete CDS of VP28 gene as an insert) was gel purified by using the Wizard ${ }^{\circledR}$ SV Gel and PCR Clean-Up System (Promega, Madison, WI, USA). From a serial dilution of the purified recombinant plasmid, the standard was prepared in a linear logarithmic scale of $1.0 \times 10^{9}$ to $10^{2}$ copies per reaction. In brief, all the qPCR reactions had a final volume of $25 \mu \mathrm{L}$ and were run in the Applied Biosystems ${ }^{\circledR} 7500$ Real-Time PCR system (Foster City, CA, USA) by using $2 \times$ SYBR $^{\circledR}$ Green PCR Master Mix (Applied Biosystems, Foster City, CA, USA), $100 \mathrm{nM}$ of the forward and reverse primers and variable quantity of each template DNA. The parameters for thermal cycling were set for an initial denaturation step at $95{ }^{\circ} \mathrm{C}$ for $10 \mathrm{~min}$ followed by 40 cycles at $95^{\circ} \mathrm{C}$ for $15 \mathrm{~s}$ for DNA denaturation with subsequent annealing and extension at $53{ }^{\circ} \mathrm{C}$ for $30 \mathrm{~s}$. The melt curve was analyzed to differentiate the specific amplicon formed by primer dimer or generation of any non-specific product. Furthermore, the qPCR products were electrophoresed in agarose gel to invalidate the existence of any spurious amplicon. The experiment was performed with duplicate replication for the purpose of quantifying the viral load. The WSSV load per gram of tissue sample was calculated using the following equation:

Viral load per gram tissue $=[$ viral load per reaction $\times($ Final Elution volume $/$ volume of template DNA per reaction) $\times$ dilution factor] \pm Standard Deviation (SD).

To evaluate the standard curve's reproducibility, standard reactions were performed three times separately, including duplications of each reaction. The data obtained from real-time PCR run were analysed using 7500 software, version 2.0.6 (Applied Biosystems, Foster City, CA, USA). Statistical program Microsoft Excel 2020 was used to analyze the data, which were presented as mean \pm SD. The standard deviation of the viral load per reaction was considered during the viral load calculation. For relative virulence study, viral copy numbers in the challenged shrimp PL were quantified per reaction with the same amount of the initial concentration of DNA. The VP28 gene amplified through real-time PCR produced a 148 bp product (Figure S1B).

\subsection{Sequencing of VP28 Protein, Phylogenetic and Mutation Analyses}

Conventional PCR-amplified products were purified with the Wizard ${ }^{\circledR}$ SV Gel and PCR Clean-Up System (Promega, Madison, WI, USA), and the seven (shrimp = 5; crab = 2) purified PCR products were exposed to an automated dideoxy cycle sequencing reaction using BigDye ${ }^{\circledR}$ Terminator v3.1 cycle sequencing kit (Applied Biosystems ${ }^{\circledR}$, Foster City, CA, USA) according to manufacturer's instruction [20]. A sequence cleaner (https:/ / github.com/metageni/Sequence-Cleaner, accessed on 20 June 2020) with set parameters of minimum length $(\mathrm{m}=3822)$, percentage $\mathrm{N}(\mathrm{mn}=0)$, keep_all_duplicates, and remove_ambiguous was used to remove all ambiguous and low-quality sequences [32]. The raw sequence data were assembled through SeqMan version 7.0 (DNASTAR, Inc., 
Madison, WI, USA) and the assembled sequences were compared with other entries from NCBI GenBank [33] with BLAST [34] search to disclose the identification and matching with VP28 gene of WSSV.

Using Molecular Evolutionary Genetics Analysis (MEGA) version 7.0 for the larger datasets [35], the VP28 gene sequences, amplified from seven isolates, were aligned with each other, and with relevant reference sequences from our previous study $(n=17)$ and NCBI GenBank database $(n=10)$, with $>90 \%$ taxonomic identity. A maximum-likelihood tree was generated with the Tamura-Nei evolutionary model $[35,36]$. Nodal confidence in resulting phylogenetic relationships was evaluated using bootstrap test (1000 replicates) [37]. Seven VP28 sequences of WSSV different isolates of shrimp and crab and 143 reference sequences of VP28 retrieved from GenBank were subjected to multiple alignment through MAFFT [38], and some adjustments were made by manual editing. Repeat units of each isolate were annotated using Geneious Prime (Trial Version), and aligned against a reference sequence for amino-acid (aa) variability score counting $[39,40]$.

\subsection{Experimental Infection}

P. monodon post larvae (PL) were collected from Meghna Shrimp Hatchery, Cox's Bazar, Bangladesh with a length of 1-2 cm. WSSV-free breeder wild-caught mother shrimps' eggs were used for hatching these post larvae in the hatchery. Highly infected black tiger shrimp tissue was used for preparing WSSV inoculum. Tissue below carapace from affected shrimp was minced and homogenized in sterile sea water. Supernatant was collected after centrifugation at $8515 \times g$ for five min and filtered through a $0.45 \mu \mathrm{m}$ membrane. Stock was diluted to prepare infective dose containing $10^{8}$ copies per mL. Blank inoculums were prepared using the same steps from a WSSV-negative shrimp sample. For in vivo challenge, we performed the previously established 'immersion technique' [41] as waterborne inoculation [42]. The experimental groups were challenged by the immersion technique in aerated glass jars ( $n=180$, in each jar) with WSSV solutions in three treatments. Using the WSSV-negative inoculums, aerated jars were set to treat the negative control group ( $n=180$ in each jar) with three treatments. The PL were fed with commercially available artificial feed once a day at a rate of $10 \%$ body weight. Mortalities were checked after every six hours, and the presence of WSSV was checked by conventional PCR (Figure S1C).

Virulence determination assay was performed in separate experiments with three treatments of shrimp PL ( $n=360$, in each jar) infected with inoculums containing the same copy number of both phylogroups (BD1 and BD2). A negative control group with three treatments ( $n=360$, in each jar) was maintained with inoculum prepared from the WSSV-negative tissue. So, the total number of jars used was nine. Thus, inocula were prepared using the abovementioned procedure from tissue with same copy numbers of the virus $\left(4.27 \times 10^{9}\right)$ from both groups and added in the small aquariums for treatments. Infective doses consisted of filtrates from the tissue of both groups containing $0.423 \times 10^{9}$ and $0.423 \times 10^{7}$ copies of WSSV per $\mathrm{mL}$ in sterile sea water. The temperature of the experimental tanks' water ranged between $28-29{ }^{\circ} \mathrm{C}$, while the salinity and dissolved oxygen were $18 \mathrm{ppt}$ and 5-6 ppm, respectively, throughout the experiment. Time-dependent mortality rates were measured by counting the number of dead PL in every six-hour interval. DNA from challenged PL (infected and control) were extracted and tested for viral load estimation by real-time PCR. $C_{T}$ values and copy number of WSSV obtained from different samples were compared.

Another pilot study of infection assay was conducted on 45 mud crabs using the tissues from both phylotypes (BD1 and BD2) through the ingestion method. The crabs were collected from a certified WSSV-free crab farm of Satkhira district. Moreover, we also tested the health status of the crabs through conventional PCR before experimental infection. The crabs were divided into three groups: Group $-1=15$ crabs challenged with BD1, Group-II = 15 crabs challenged with BD2, and Group-III = 15 crabs, serving as control . The crabs were of 6 months of age, and each group was kept in a separate tank containing 5 crabs in each. Crabs of the treated groups were fed with infected crab tissue (Day 1) and 
trash fish (from Day 2), while crabs of the control group were given beef liver from the first day [42]. Tissues containing both groups of WSSV $\left(1.0 \times 10^{9}\right)$ were used to feed the crabs of the experimental groups. Standard experimental conditions were similar to the shrimp PL virulence experiment other than the salinity, which was maintained at a higher level (28-30 ppt).

\subsection{RNA Extraction and Preparation of $c D N A$}

RNA was extracted from the challenged PL at the moribund stage using QIAgen's QIAamp Viral RNA mini kit according to the protocol of manufacturer. The purity and concentration of the extracted RNA were assessed by Nanodrop-2000 spectrophotometer. The extracted RNA was reverse-transcribed to cDNA using New England Biolab's cDNA kit (PhotoScript II First Strand cDNA Synthesis Kit, New England Biolabs, Ipswich, MA, USA).

\subsection{Gene Expression Analysis}

Real-time PCR was used for the analysis of expression of two immunity genes of shrimps (Penaeidin and Lysozyme). Quantitative PCR was run with one cycle of initial denaturation at $95^{\circ} \mathrm{C}$ for $60 \mathrm{~s}$ and 45 cycles of denaturation at $95^{\circ} \mathrm{C}$ for $15 \mathrm{~s}$ and extension at $60^{\circ} \mathrm{C}$ for $30 \mathrm{~s}$ using New England Biolab's Luna Universal qPCR master mix according to the protocol of manufacturer. The primers used are presented in Table 1. Averagefold difference in gene expression was analysed by comparative delta $C_{T}$ method [43]. Housekeeping gene beta-actin was used for normalization that provided the $C_{T}$ values as internal (endogenous) control. Control treatments were inoculated with inoculum prepared from WSSV-negative tissue, and the samples were considered for gene expression if there was any amplification. Delta $C_{T}$ has been calculated by deducting $C_{T}$ value of endogenous control from the gene of target, and finally, mean delta $C_{T}$ was calculated from this standardized delta $C_{T}$ value. Delta $C_{T}$ was calculated with reference to the control by deducting the mean delta $C_{T}$ of the control from the mean delta $C_{T}$ of the target gene. Changes in average-fold gene expression in challenged PL was calculated to $2^{\text {-delta delta } C_{T}}$ values.

Table 1. Primers used in the current study.

\begin{tabular}{lll}
\hline Name of Gene & Primer Sequence $\left(5^{\prime}-\mathbf{3}^{\prime}\right)$ & Reference \\
\hline \multirow{2}{*}{ Penaeidin } & F: TGGTCTGCCTGGTCTTCCT & {$[44]$} \\
\hline R: AAGCACGAGCTTGTAAGGG & F: TGGTGTGGCAGCGATTATG \\
& R: GATCGAGGTCGCGATTCTTAC & {$[44]$} \\
\hline Beta-actin & $\begin{array}{l}\text { F: CCCTGTTCCAGCCCTCATT } \\
\text { R: GGATGTCCACGTCGCACTT }\end{array}$ & {$[45]$} \\
\hline VP28 & F: GCGCGCGGATCCAATCATGGATCTTTCTTTCAC \\
\hline RVP28 & F: TGTGCGCGAATTCTTACTCGGTCTCAGTGCC \\
& R: CTTGATTTTGCCCAAGGTGT & {$[30]$} \\
\hline
\end{tabular}

\subsection{Observation of Binding Affinity of VP28 and Its Receptor Protein Rab7}

The web server PRODIGY was used to observe the binding affinity of the receptor protein Rab7 and the WSSV envelope protein VP28 of both groups from Bangladesh [46,47]. VP28 with glycine at its 167th amino acid position and VP28 with glutamic acid at 167th amino acid position were used for docking with Rab7 of P. monodon by HADDOCK (High Ambiguity Driven protein-protein DOCKing) [48]. For protein-protein docking, active residues [48] were produced from both molecules. Prior to docking, the Rab7 sequences were downloaded from the NCBI database and the homology modelling of Rab7 protein was conducted using SWISS-MODEL and validated further by developing Ramachandran plots [49]. PROGIDY used interactors from both proteins for producing binding affinity 
$(\Delta \mathrm{G})$ and the dissociation constant $(\mathrm{Kd})$ values. Moreover, DynaMut web server was used to observe the impact of this mutation to the stability of the VP28 [50].

\subsection{Statistical Analysis}

The salinity, temperature, dissolved oxygen and $\mathrm{pH}$ were compared to WSSV, grouped as present and absent. In the case of salinity, temperature and dissolved oxygen, nonparametric independent sample tests were performed, and for $\mathrm{pH}$, a parametric independent sample test was performed. The null hypothesis of the distribution of physicochemical parameters was the same across categories of WSSV and was retained for dissolved oxygen and $\mathrm{pH}$ and rejected for salinity and temperature. When there is no significant interaction between time and isolate, the probit model takes the form: probit $(x)=\alpha+\beta$ time $+\gamma$ isolate, where $\alpha$ is the intercept, $\beta$ is the rate of probability change per unit change of time (for a constant isolate), and $\gamma$ is the rate of probability. Eta test statistic was used to study the associations between WSSV (nominal variable) and the physicochemical parameters (scale variables). Additionally, the mean prevalence of WSSV among different regions was calculated using SPSS (SPSS, Version 23.0, IBM Corp., New York, NY, USA) [51]. Final values for average-fold differences in gene expression were tested for significance at the $5 \%$ level using $t$-test.

\section{Results}

\subsection{Prevalence of WSSV and Physicochemical Parameters in the Study Ghers}

The overall prevalence of WSSV in both crustacean population (shrimp and crab) between the study areas (Cox's Bazar and Satkhira) and over the study periods (2017-2019) differed significantly ( $p<0.05$, Kruskal-Wallis test). The average prevalence of WSSV during 2017 to 2019 in shrimp and crabs were $20.93 \%$ and $12.73 \%$ in the ghers of Cox's Bazar, and $16.73 \%$ and $9.53 \%$ in the ghers of Satkhira, respectively (Figure 2A). By comparing the year-wise prevalence of WSSV in the shrimp between the study areas, the highest prevalence was recorded in the shrimp ghers of both Cox's Bazar (23.11\%) and Satkhira $(18.96 \%)$ in 2017 , and WSSV infection rates in shrimp population gradually decreased thereafter in 2018 and 2019 (Figure 2A). Conversely, the prevalence of WSSV in the crab population was found to be highest in the ghers of Cox's Bazar (14.16\%) in 2019 and Satkhira (10.54\%) in 2018 (Figure 2A). Physicochemical parameter analysis of the study ghers showed that the mean value of salinity, dissolved oxygen, temperature and $\mathrm{pH}$ ranged from 14-16 ppt, 3.6 to $3.8 \mathrm{ppm}, 33.9$ to $34^{\circ} \mathrm{C}$ and $7.8-8.4$, respectively, in the WSSVpositive shrimp ghers, and 13-21 ppt, 2.61 to $6.06 \mathrm{ppm}, 28.7$ to $34{ }^{\circ} \mathrm{C}$ and 8.2 to 9.1 in WSSV-negative ghers (Tables 2 and S1). Comparing the physicochemical parameters across the study ghers, we found higher water temperature in WSSV-positive ghers compared to WSSV-negative ghers. Likewise, the WSSV-negative ghers also had higher salinity than WSSV-positive ghers (Figure 2B).

Table 2. Physicochemical parameters in the shrimp and crab ghers.

\begin{tabular}{|c|c|c|c|c|c|c|}
\hline Gher ID & Salinity (ppt) & $\begin{array}{l}\text { Dissolved Oxygen } \\
\text { (ppm) }\end{array}$ & $\begin{array}{c}\text { Temperature } \\
\left({ }^{\circ} \mathrm{C}\right)\end{array}$ & $\mathrm{pH}$ & $\begin{array}{c}\text { Shrimp Samples } \\
\text { Selected }\end{array}$ & $\begin{array}{c}\text { Crab Samples } \\
\text { Selected }\end{array}$ \\
\hline Cox1 & 14 & 3.8 & 33.9 & 8.4 & 18 & 6 \\
\hline Cox2 & 21 & 3.75 & 33.7 & 8 & 18 & 6 \\
\hline Cox3 & 21 & 3.65 & 33.7 & 7.8 & 18 & 6 \\
\hline Cox 4 & 20 & 3.90 & 33 & 8.1 & 18 & 6 \\
\hline Cox5 & 20 & 3.70 & 32.9 & 8.2 & 18 & 6 \\
\hline SS1 & 14 & 3.8 & 34 & 8.5 & 18 & 6 \\
\hline SS2 & 15 & 3.6 & 33.7 & 8.6 & 18 & 6 \\
\hline SS3 & 15 & 3.7 & 34 & 7.8 & 18 & 6 \\
\hline D1 & 19 & 3.8 & 33.8 & 7.8 & 18 & 6 \\
\hline $\mathrm{D} 2$ & 17.5 & 3.7 & 33.5 & 8 & 18 & 6 \\
\hline
\end{tabular}


Table 2. Cont.

\begin{tabular}{|c|c|c|c|c|c|c|}
\hline Gher ID & Salinity (ppt) & $\begin{array}{l}\text { Dissolved Oxygen } \\
(\mathrm{ppm})\end{array}$ & $\begin{array}{c}\text { Temperature } \\
\left({ }^{\circ} \mathrm{C}\right)\end{array}$ & $\mathrm{pH}$ & $\begin{array}{l}\text { Shrimp Samples } \\
\text { Selected }\end{array}$ & $\begin{array}{c}\text { Crab Samples } \\
\text { Selected }\end{array}$ \\
\hline D3 & 20 & 3.6 & 33 & 8.6 & 18 & 6 \\
\hline A1 & 16.5 & 3.5 & 33.3 & 7.7 & 18 & 6 \\
\hline $\mathrm{A} 2$ & 16 & 3.8 & 33.8 & 7.8 & 18 & 6 \\
\hline $\mathrm{A} 3$ & 15 & 3.6 & 34 & 8 & 18 & 6 \\
\hline K1 & 14 & 3.8 & 34.6 & 8.6 & 18 & 6 \\
\hline $\mathrm{K} 2$ & 15 & 3.6 & 34.7 & 7.8 & 18 & 6 \\
\hline $\mathrm{K} 3$ & 16 & 3.6 & 33.9 & 7.9 & 18 & 6 \\
\hline $\mathrm{S} 1$ & 13 & 3.6 & 33.9 & 7.9 & 18 & 6 \\
\hline $\mathrm{S} 2$ & 16 & 3.8 & 34 & 8.1 & 18 & 6 \\
\hline S3 & 16 & 3.7 & 34 & 8 & 18 & 6 \\
\hline
\end{tabular}

Gher prefix started with C represents the ghers from Cox's Bazar while others represent the ghers of Satkhira districts.

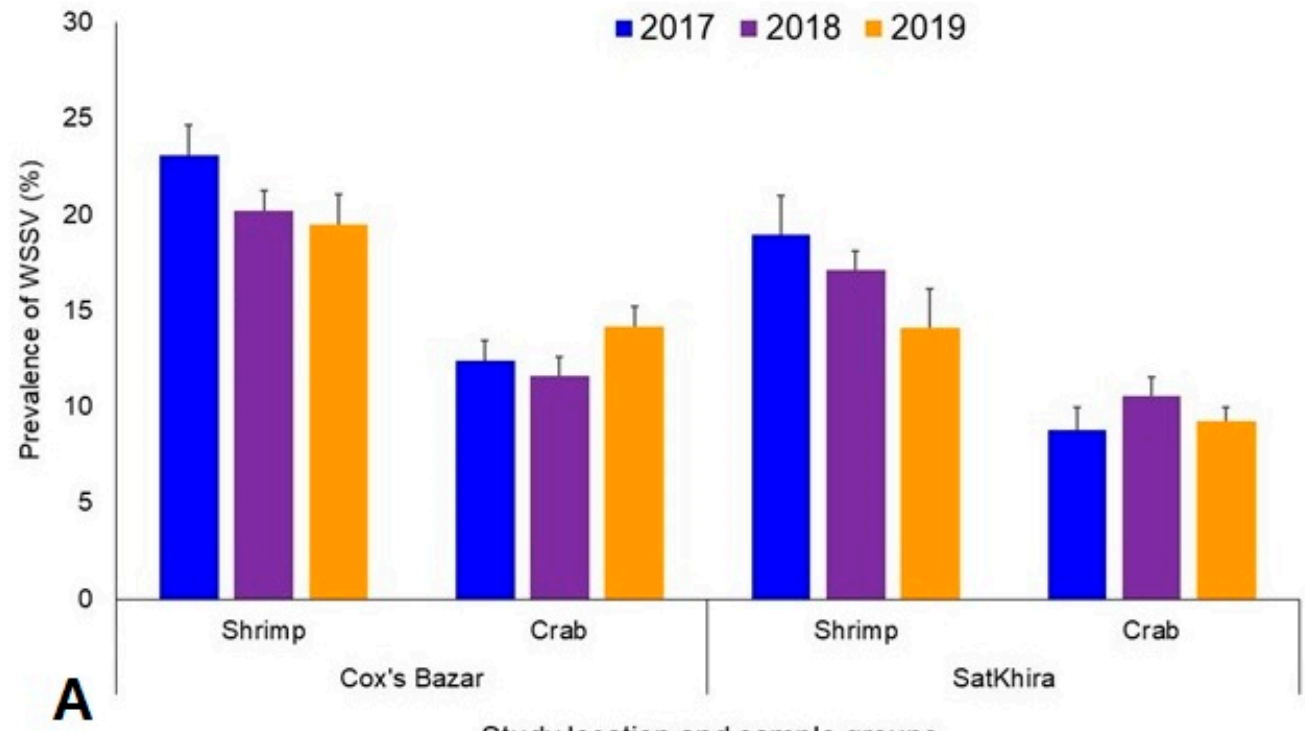

Study location and sample groups

Mean temperature $\left({ }^{\circ} \mathrm{C}\right)$ and salinity $(\mathrm{ppt})$

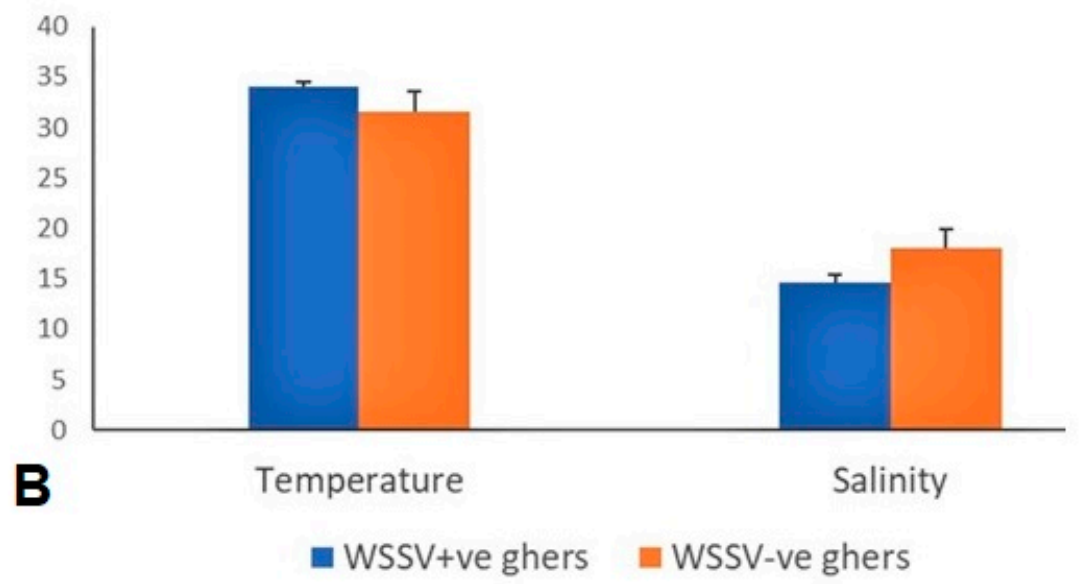

Figure 2. Prevalence of WSSV in Bangladesh. (A). The overall prevalence of WSSV in shrimp and crabs in two different regions (Cox's Bazar and Satkhira) of Bangladesh during 2017-2019. (B) Mean temperature and salinity of shrimp ghers which differed significantly between WSSV+ve and WSSV-ve ghers. 


\subsection{Detection of WSSV in Scylla Olivacea}

One of the hallmark findings of this study was the detection of WSSV in the mud crabs (Scylla olivacea) in the samples of both regions, Cox's Bazar and Satkhira. The appearance of a $643 \mathrm{bp}$ PCR product confirmed the presence of WSSV in the crabs (Figure S1A).

\subsection{Viral Loads in Circulating Phylotypes of WSSV Differed in Crustacean Samples}

In the current study, WSSV Log load per gram of shrimp tissue ranged from 7.62 (Cox's Bazar) to 12.35 (Satkhira), while that of crab tissue ranged from 8.20 (Cox's Bazar) to 10.47 (Satkhira) (Figure 3). On average, shrimp samples from Satkhira had significantly higher $(p<0.05$, Kruskal-Wallis test) viral load (10.48 \pm 0.32 , SEM) than that of Cox's Bazar ( $8.40 \pm 0.08, \mathrm{SEM})$. The viral load in crab samples also varied significantly $(p<0.05$, Kruskal-Wallis test) in the study areas, keeping a higher load (9.92 \pm 0.56, SEM) in Satkhira compared to samples from Cox's Bazar (8.91 \pm 0.72, SEM) (Figure 3).

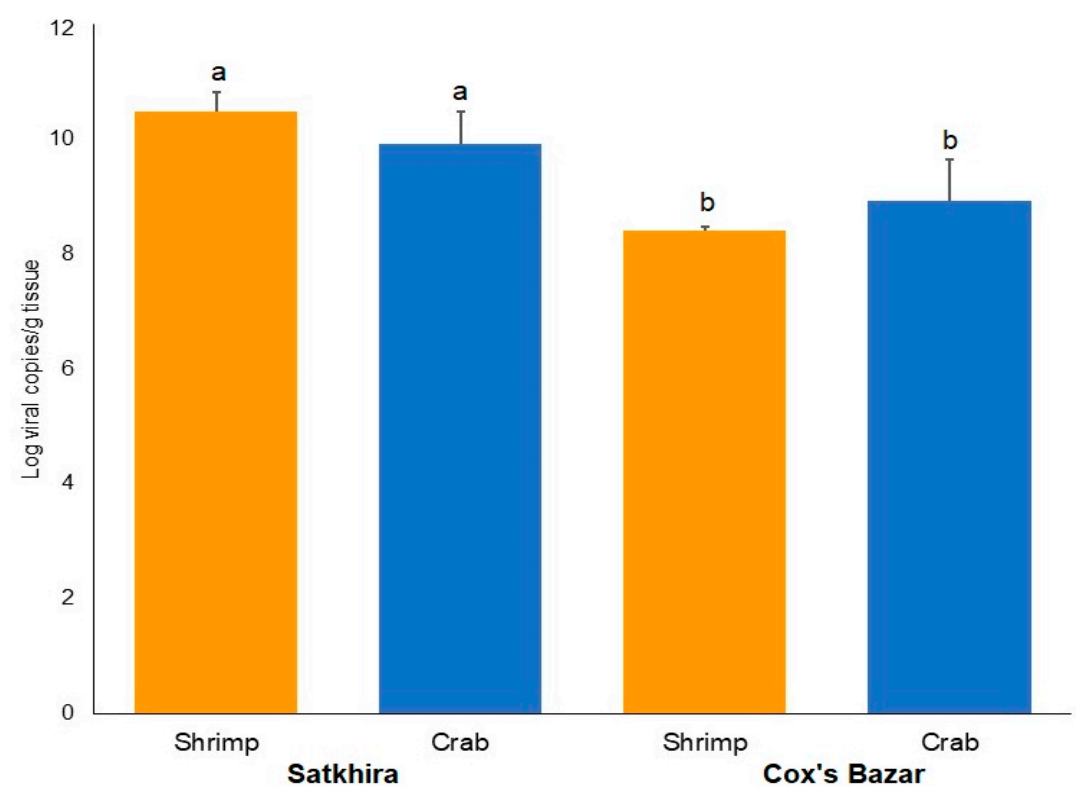

Figure 3. Viral load in crustacean (shrimp and crab) samples in Cox's Bazar and Satkhira. Error bars represent standard deviation, and superscripts $(a, b)$ represent significant differences $(p<0.05)$ statistical analysis.

The VP28 gene-based phylogenetic analysis divided the isolates into two major phylotypes (BD1 and BD2) which are currently circulating across the country. Nucleotide sequences obtained from seven crustacean isolates according to VP28 gene sequencing (2017-2019) along with 17 previously reported reference sequences (2014-2015) from Bangladesh (our laboratory) and 10 reference sequences retrieved from NCBI database were used to generate a phylogenetic tree. Two clusters (BD1 and BD2) contained 24 of the sequences isolated from Bangladesh that mostly related to isolates from India and Vietnam. The phylotype BD1 and BD2 contained 8 and 16 isolates of WSSV, respectively (Figure 4A). Two isolates (MZ383193 and MZ383194) belonging to the phylotype BD1 had 98-100.0\% similarity with six VP28 gene sequences reported previously from Bangladesh (2015 and 2017), and that of two Indian sequences (Figure 4A). The isolates of the BD1 phylotype formed a slightly distant branch with VP28 gene sequences reported from other countries such as China, South Korea and Vietnam. On the other hand, the isolates of BD2 phylotype (MZ383195-198) were found to be closely clustered with other VP28 sequences that was previously reported (2014-2015) to be circulated in Bangladesh (Figure 4A). 


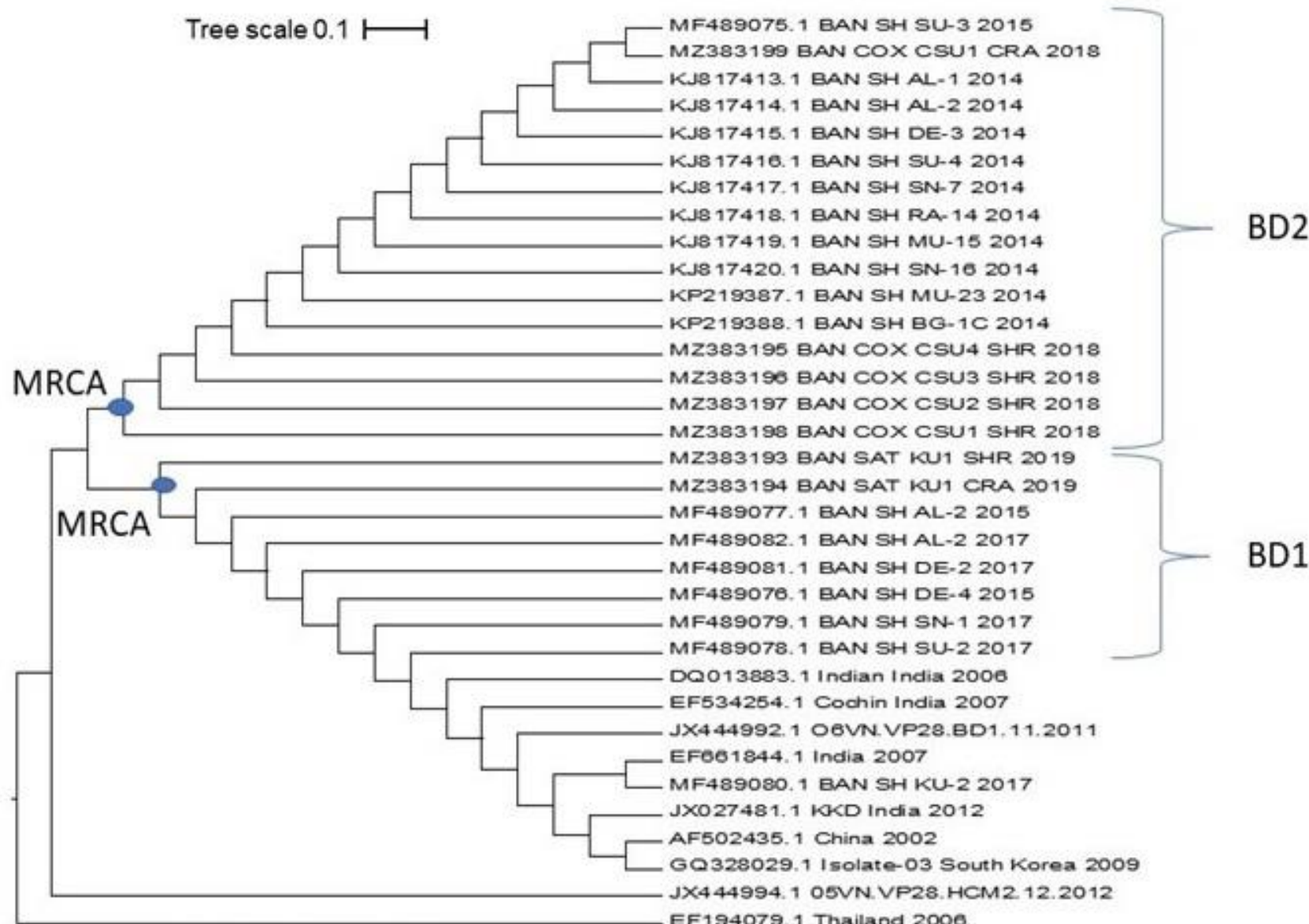

\section{A}

$\begin{array}{lllllllllllll}150 & 152 & 154 & 156 & 158 & 160 & 162 & 164 & 166 & 168 & 170 & 172 & 174\end{array}$

DQ681069.1_Shrimp_WSSV 150 V G S S N T S S F T P V S I D E D E V G T F V C G T BAN_SAT_KU1_SHR_2019

BAN_SAT_KU1_CR_2019

BAN_COX_CSU4_SHR_2018

120 V G S S N T S SF T P V S I DE DE V G TFV C G T 130 V G S S N T S F T P V S I D D E V G T V C G T

$B A N \_C O X \_C S U 3 \_S H R \_2018$

112 V GS SNTSSFTPVSI DE D G V G T F V C G T

$B A N \_C O X \_C S U 2$ SHR_2018

150 V G S S N T S F T P V S I D D G V G T F V C G T

BAN_COX_CSU1_SHR_2018

150 V G S S T S S F T P V I D E D G V T F V C G T

BAN_COX_CSU1_CR_2018

$150 V G S S N T S S F T P V S I D E D G V G T F V C G T$

131 V G S S N T S S F T P V I D E D G V G T F C G T

B

Figure 4. VP28 gene-based phylogenetic analysis. (A) Two phylotypes (BD and BD2) are currently circulating across the country. (B) Amino acid (aa) mutations in the VP28 sequences of WSSV.

\subsection{Variations in Amino-Acid Mutations in VP28 of WSSV}

For amino acid (aa) mutation analysis, we used one VP28 reference sequence from the Thai isolate (GenBank Accession no. AF369029). Out of 150 VP28 sequences retrieved from the NCBI database (including 24 sequences from our laboratory), 104 (69.33\%) sequences showed aa mutations at 21 positions. Among these mutations, residue position 42 (33.33\%), $114(8 \%)$ and $167(12.67 \%)$ were found as the major mutation sites in the VP28 sequences of WSSV (Figures S2 and S3). However, residue position 167 showed glycine instead of glutamic acid $(\mathrm{E} \rightarrow \mathrm{G})$ in 19 VP28 sequences, including 15 from Bangladeshi and four from Egyptian sequences (Figure S2). Of the Bangladeshi sequences, 10 were obtained from previous studies from our laboratory [20,29], and the rest of the five (GenBank Accession no. MZ383195-MZ383199) were from the current study. Moreover, in the current study, two 
VP28 sequences of both shrimp (GenBank Accession no. MZ383193) and crab (GenBank Accession no. MZ383194) isolates from Satkhira had E at the 167 residue position unlike the five sequences (GenBank Accession no. MZ383199; crab sample, and GenBank Accession no. MZ383195-MZ383198; shrimp samples) of Cox's Bazar with G in that position (Figure 4B).

\subsection{Shrimp Post-Larvae Mortality Rates and Lethal Time Differed between Phylotypes}

The survival of shrimp post larvae (PL) between control and infected groups was statistically significant $(p<0.05$, Kruskal-Wallis test) in all of our experiments of the current study. Shrimp PL when challenged with confirmed WSSV irrespective of the mentioned phylotypes showed a mortality rate of $96.67 \%$ at $96 \mathrm{~h}$ with a dose of $10^{8}$ copies of WSSV per $\mathrm{mL}$ of sterile seawater (Figure 5) in which the mortality observation took place every $6 \mathrm{~h}$. In the present infection assay with three treatments, shrimps started to die at $48 \mathrm{~h}$ and lasted till $108 \mathrm{~h}$, while shrimps in the control group did not die before those were sacrificed. By comparing the virulence assay between challenged doses, we found that shrimp PL challenged with Dose $1\left(0.423 \times 10^{9}\right.$ copies of WSSV per $\left.\mathrm{mL}\right)$ started to die after $66 \mathrm{~h}$ of challenge, and $100 \%$ mortality of PL occurred at $102 \mathrm{~h}$ after challenge with both phylotypes. However, using Dose $2\left(0.423 \times 10^{7}\right.$ copies of WSSV per $\left.\mathrm{mL}\right)$, the onset of shrimp PL mortality started at $72 \mathrm{~h}$ of challenge, and $100 \%$ mortality was found after $108 \mathrm{~h}$ and $114 \mathrm{~h}$ of challenge with BD1 and BD2, respectively (Figures 6 and S1C). The average median LT50 values were observed to be 73 and $75 \mathrm{~h}$ post infection (hpi), respectively, in BD1- and BD2-challenged shrimp PL with Dose 1, and 82 and 84 hpi with Dose 2 (Figure 6). However, this difference in median LT50 between the two phylotypes with both doses was not statistically significant $(p>0.05)$. In addition to these factors, doses and viral phylotypes, the shrimp PL's physiological conditions and capacity to adapt in aquariums could also be the factors engaged in mortality. For that reason, viral load count in the infected PL tissue might help in revealing the study goal more accurately. Additionally, from that perspective, the quantification of the virus using real-time PCR assay was a major part of this study.

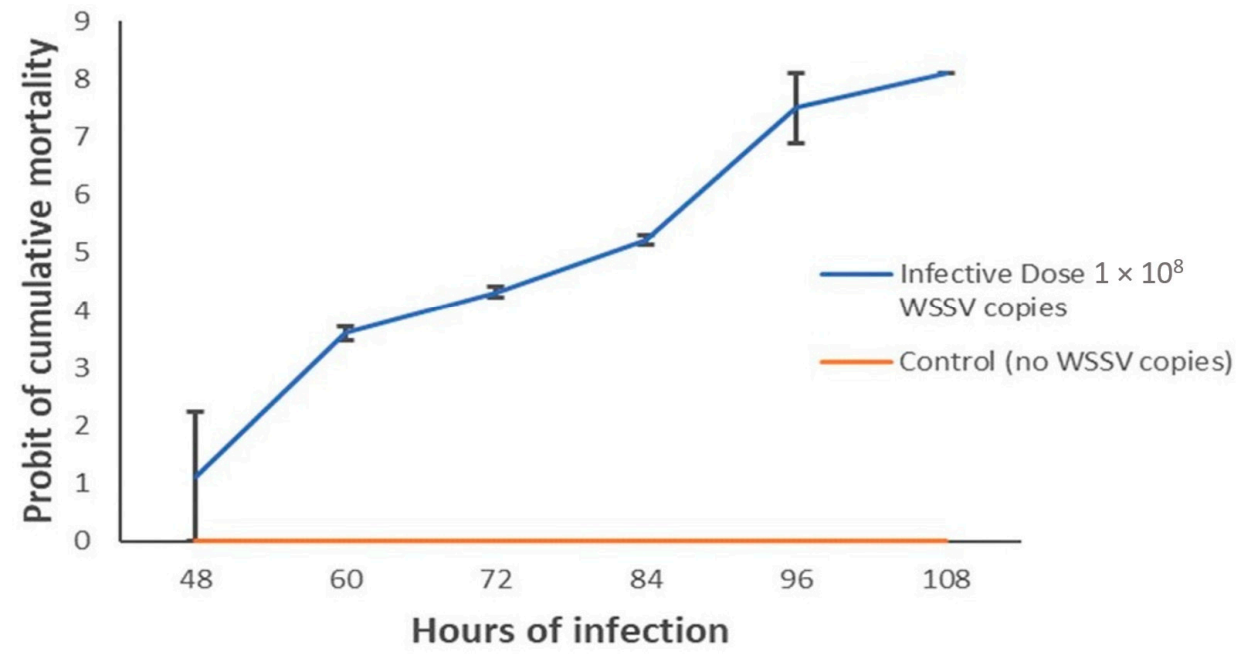

Figure 5. Probit of mortality. The $Y$-axis represents the morality rates while the $X$-axis shows the $h$ of challenge. 


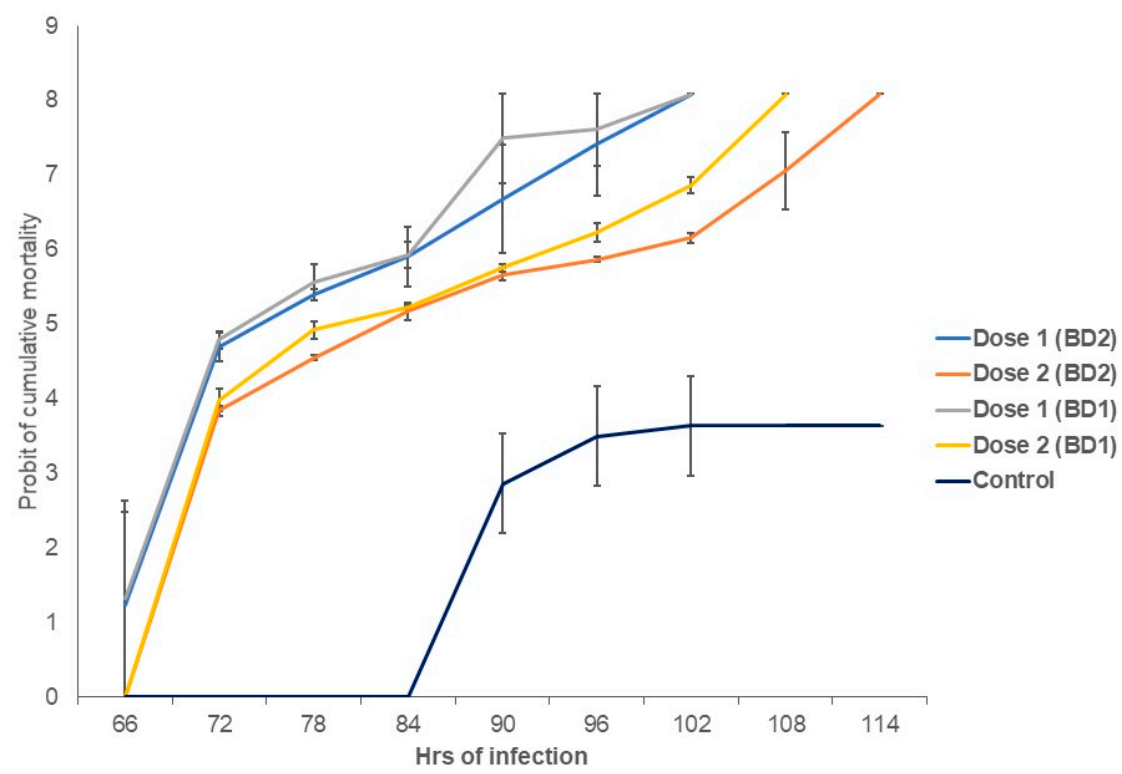

Figure 6. Probit of cumulative mortality after challenge with BD1 and BD2 phylotypes. The $Y$-axis represents the morality rates while the $X$-axis shows the $h$ of challenge.

\subsection{Quantitative Detection of WSSV in Challenged Shrimp PL}

The mean Log viral copy numbers were 6.47 and 4.75 per mg of tissue, respectively in BD1- and BD2-treated PL, which was statistically significant $(p<0.05$, Kruskal-Wallis test) with Dose 1 (Figure 7). In this study, we found an average $C_{T}$ value of 20.01 and 25.32 in BD1- and BD2-challenged PL, respectively (Table 3, Figure S1B). Figure 8 shows the positive amplifications in samples challenged with both phylogroups, positive controls and standards. In this quantitative assay, an extensive range of the mean viral Log load in challenged shrimp PL was observed, and the results showed that amplification curves were specific for samples, standards, negative controls and positive controls. No noteworthy fluorescence signal was noted for the negative control (NTC). $C_{T}$ values for NTC were outside determination index, and $\mathrm{C}_{\mathrm{T}}$ values in all positive samples had a quantitative index in qPCR, ranging from 7.19 to 33.48 (Figure 8A). Standard qPCR using the qVP28F and qVP28R primers revealed a single amplicon of $148 \mathrm{bp}$ after agarose gel electrophoresis, indicating a specific amplification product. The standard curve generated was linear from log starting quantity of 2 to 9 . The mean upper and lower quantification limits in challenged shrimp PL were $1.10 \times 10^{10}$ and $3.31 \times 10^{2}$ WSSV copies per mg tissue, respectively (Figure 8A,B). 


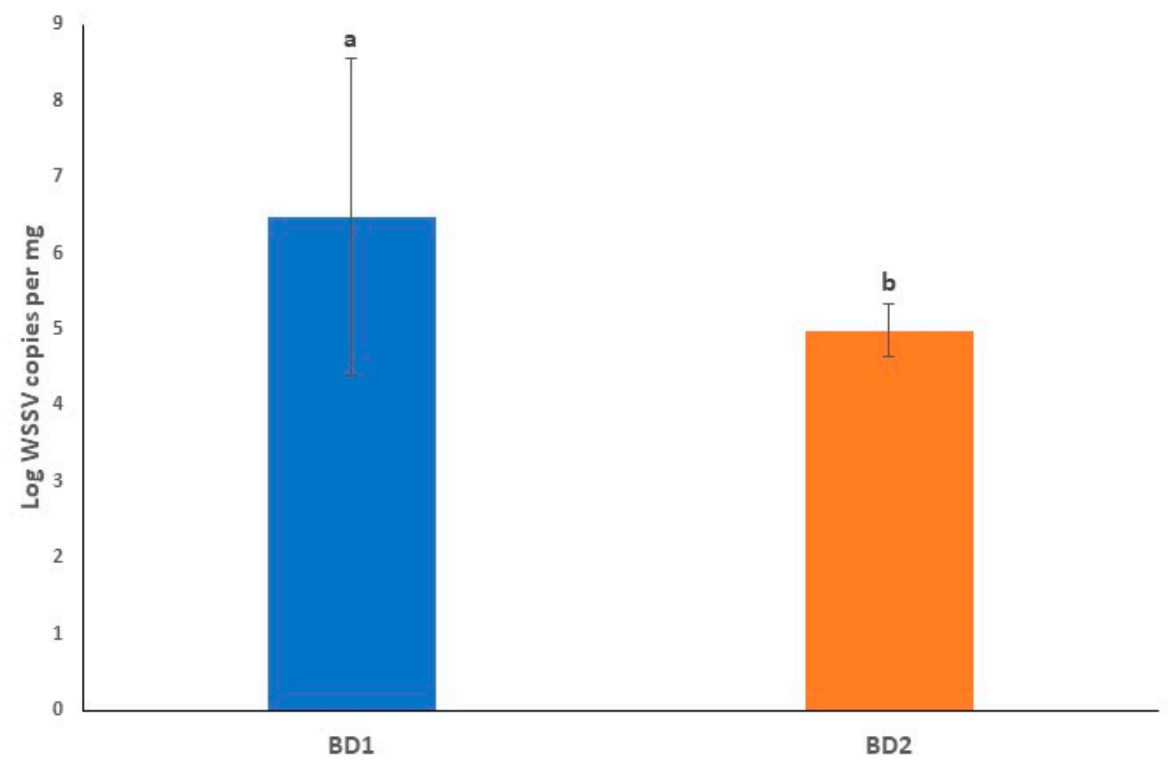

Figure 7. Log WSSV copies per mg of tissue infected with BD1 and BD2. Error bars and 'alphabets' represent the standard deviation and significant difference $(p<0.05)$, respectively.

Table 3. $C_{T}$ values and corresponding WSSV copies from the quantitative real-time PCR (E and G of sample IDs mean samples challenged with BD1 and BD2).

\begin{tabular}{|c|c|c|c|c|c|c|c|c|}
\hline $\begin{array}{l}\text { Sample } \\
\text { ID }\end{array}$ & $\mathrm{CT}$ & $\mathrm{CT}$ & CT Mean & CT SD & $\begin{array}{l}\text { WSSV } \\
\text { Copies }\end{array}$ & $\begin{array}{l}\text { WSSV } \\
\text { Copies }\end{array}$ & $\begin{array}{c}\text { Mean WSSV } \\
\text { Copies/Reaction }\end{array}$ & $\begin{array}{c}\text { Mean WSSV } \\
\text { Copies/mg } \\
\text { Tissue }\end{array}$ \\
\hline G1 & 27.09 & 27.21 & 27.15 & 0.085 & $2.74 \times 10^{3}$ & $2.52 \times 10^{3}$ & $2.63 \times 10^{3}$ & $2.59 \times 10^{4}$ \\
\hline G2 & 25.61 & 25.9 & 25.755 & 0.205 & $7.53 \times 10^{3}$ & $6.21 \times 10^{3}$ & $6.87 \times 10^{3}$ & $8.41 \times 10^{4}$ \\
\hline G3 & 28.80 & 29.02 & 28.91 & 0.156 & $8.50 \times 10^{2}$ & $7.35 \times 10^{2}$ & $7.93 \times 10^{2}$ & $1.03 \times 10^{4}$ \\
\hline G4 & 25.83 & 25.77 & 25.80 & 0.042 & $6.45 \times 10^{3}$ & $6.74 \times 10^{3}$ & $6.60 \times 10^{3}$ & $7.76 \times 10^{4}$ \\
\hline G5 & 25.29 & 25.38 & 25.34 & 0.064 & $9.37 \times 10^{3}$ & $8.78 \times 10^{3}$ & $9.08 \times 10^{3}$ & $5.56 \times 10^{4}$ \\
\hline G6 & 26.05 & 25.77 & 25.91 & 0.198 & $5.55 \times 10^{3}$ & $6.72 \times 10^{3}$ & $6.14 \times 10^{3}$ & $6.94 \times 10^{4}$ \\
\hline G7 & 25.30 & 25.35 & 25.325 & 0.035 & $9.31 \times 10^{3}$ & $8.98 \times 10^{3}$ & $9.15 \times 10^{3}$ & $1.28 \times 10^{5}$ \\
\hline G8 & 26.10 & 26.67 & 26.385 & 0.403 & $5.37 \times 10^{3}$ & $3.64 \times 10^{3}$ & $4.51 \times 10^{3}$ & $4.16 \times 10^{4}$ \\
\hline G9 & 28.21 & 28.47 & 28.34 & 0.184 & $1.27 \times 10^{3}$ & $1.07 \times 10^{3}$ & $1.17 \times 10^{3}$ & $1.30 \times 10^{4}$ \\
\hline G10 & 25.89 & 26.05 & 25.97 & 0.113 & $6.20 \times 10^{3}$ & $5.58 \times 10^{3}$ & $5.89 \times 10^{3}$ & $6.93 \times 10^{4}$ \\
\hline G11 & 25.74 & 24.49 & 25.12 & 0.884 & $6.87 \times 10^{3}$ & $1.61 \times 10^{4}$ & $1.15 \times 10^{3}$ & $6.89 \times 10^{4}$ \\
\hline G12 & 25.85 & 26.09 & 25.97 & 0.17 & $6.36 \times 10^{3}$ & $5.40 \times 10^{3}$ & $5.88 \times 10^{3}$ & $7.20 \times 10^{4}$ \\
\hline G13 & 25.64 & 25.86 & 25.75 & 0.156 & $7.36 \times 10^{3}$ & $6.34 \times 10^{3}$ & $6.85 \times 10^{3}$ & $7.34 \times 10^{4}$ \\
\hline G14 & 25.32 & 25.36 & 25.34 & 0.028 & $9.16 \times 10^{3}$ & $8.89 \times 10^{3}$ & $9.03 \times 10^{3}$ & $6.85 \times 10^{4}$ \\
\hline G15 & 24.30 & 24.52 & 24.41 & 0.156 & $1.83 \times 10^{4}$ & $1.58 \times 10^{4}$ & $1.71 \times 10^{4}$ & $2.44 \times 10^{5}$ \\
\hline G16 & 25.70 & 25.46 & 25.58 & 0.170 & $7.07 \times 10^{3}$ & $8.33 \times 10^{3}$ & $7.67 \times 10^{3}$ & $7.55 \times 10^{4}$ \\
\hline G17 & 24.52 & 24.70 & 24.61 & 0.127 & $1.58 \times 10^{4}$ & $1.40 \times 10^{4}$ & $1.49 \times 10^{4}$ & $1.82 \times 10^{5}$ \\
\hline G18 & 27.10 & 26.92 & 27.01 & 0.127 & $2.72 \times 10^{3}$ & $3.07 \times 10^{3}$ & $2.89 \times 10^{3}$ & $3.77 \times 10^{4}$ \\
\hline G19 & 27.40 & 27.04 & 27.22 & 0.255 & $2.22 \times 10^{3}$ & $2.83 \times 10^{3}$ & $2.5 \times 10^{3}$ & $2.95 \times 10^{4}$ \\
\hline G20 & 24.90 & 24.68 & 24.79 & 0.156 & $1.22 \times 10^{4}$ & $1.42 \times 10^{4}$ & $1.32 \times 10^{4}$ & $8.06 \times 10^{4}$ \\
\hline G21 & 24.27 & 24.37 & 24.32 & 0.071 & $1.88 \times 10^{4}$ & $1.75 \times 10^{4}$ & $1.81 \times 10^{4}$ & $2.05 \times 10^{5}$ \\
\hline G22 & 23.98 & 23.48 & 23.73 & 0.354 & $2.29 \times 10^{4}$ & $3.22 \times 10^{4}$ & $2.71 \times 10^{4}$ & $3.79 \times 10^{5}$ \\
\hline G23 & 24.00 & 24.26 & 24.13 & 0.184 & $2.26 \times 10^{4}$ & $1.89 \times 10^{4}$ & $2.06 \times 10^{4}$ & $1.91 \times 10^{5}$ \\
\hline G24 & 26.53 & 27.03 & 26.78 & 0.354 & $4.01 \times 10^{3}$ & $2.85 \times 10^{3}$ & $3.38 \times 10^{3}$ & $3.76 \times 10^{4}$ \\
\hline G25 & 23.85 & 24.35 & 24.1 & 0.354 & $2.50 \times 10^{4}$ & $1.78 \times 10^{4}$ & $2.10 \times 10^{4}$ & $2.48 \times 10^{5}$ \\
\hline G26 & 20.95 & 21.23 & 21.09 & 0.198 & $1.81 \times 10^{5}$ & $1.49 \times 10^{5}$ & $1.64 \times 10^{5}$ & $9.87 \times 10^{5}$ \\
\hline G27 & 24.63 & 25.09 & 24.86 & 0.325 & $1.47 \times 10^{4}$ & $1.07 \times 10^{4}$ & $1.25 \times 10^{4}$ & $1.54 \times 10^{5}$ \\
\hline G28 & 23.50 & 23.88 & 23.69 & 0.269 & $3.17 \times 10^{4}$ & $2.45 \times 10^{4}$ & $2.79 \times 10^{4}$ & $2.99 \times 10^{5}$ \\
\hline G29 & 23.60 & 24.08 & 23.84 & 0.339 & $2.96 \times 10^{4}$ & $2.14 \times 10^{4}$ & $2.52 \times 10^{4}$ & $1.91 \times 10^{5}$ \\
\hline G30 & 22.22 & 22.62 & 22.42 & 0.283 & $7.61 \times 10^{4}$ & $5.79 \times 10^{4}$ & $6.63 \times 10^{4}$ & $9.48 \times 10^{5}$ \\
\hline
\end{tabular}


Table 3. Cont.

\begin{tabular}{|c|c|c|c|c|c|c|c|c|}
\hline $\begin{array}{l}\text { Sample } \\
\text { ID }\end{array}$ & $\mathrm{CT}$ & $\mathrm{CT}$ & CT Mean & CT SD & $\begin{array}{l}\text { WSSV } \\
\text { Copies }\end{array}$ & $\begin{array}{l}\text { WSSV } \\
\text { Copies }\end{array}$ & $\begin{array}{c}\text { Mean WSSV } \\
\text { Copies/Reaction }\end{array}$ & $\begin{array}{c}\text { Mean WSSV } \\
\text { Copies/mg } \\
\text { Tissue }\end{array}$ \\
\hline E1 & 33.48 & 23.65 & 28.565 & 6.951 & $3.48 \times 10^{1}$ & $4.24 \times 10^{4}$ & $2.12 \times 10^{4}$ & $9.50 \times 10^{4}$ \\
\hline E2 & 32.19 & 32.35 & 32.27 & 0.113 & $8.44 \times 10^{1}$ & $7.54 \times 10^{1}$ & $7.99 \times 10^{1}$ & $8.88 \times 10^{2}$ \\
\hline E3 & 31.15 & 29.51 & 30.33 & 1.16 & $1.71 \times 10^{2}$ & $5.24 \times 10^{2}$ & $3.48 \times 10^{2}$ & $1.86 \times 10^{3}$ \\
\hline E4 & 12.37 & 7.65 & 10.01 & 3.338 & $6.0 \times 10^{7}$ & $1.59 \times 10^{9}$ & $8.25 \times 10^{8}$ & $1.10 \times 10^{10}$ \\
\hline E5 & 18.23 & 18.11 & 18.17 & 0.085 & $1.16 \times 10^{6}$ & $1.25 \times 10^{6}$ & $1.21 \times 10^{6}$ & $9.04 \times 10^{6}$ \\
\hline E6 & 30.63 & 24.20 & 27.415 & 4.547 & $2.44 \times 10^{2}$ & $1.97 \times 10^{4}$ & $9.97 \times 10^{3}$ & $1.03 \times 10^{5}$ \\
\hline E7 & 7.19 & 28.84 & 18.015 & 15.31 & $2.17 \times 10^{9}$ & $8.29 \times 10^{2}$ & $1.09 \times 10^{9}$ & $7.15 \times 10^{9}$ \\
\hline E8 & 16.38 & 16.58 & 16.48 & 0.141 & $4.10 \times 10^{6}$ & $3.56 \times 10^{6}$ & $3.83 \times 10^{6}$ & $2.74 \times 10^{7}$ \\
\hline E9 & 26.82 & 26.59 & 26.705 & 0.163 & $3.30 \times 10^{3}$ & $3.86 \times 10^{3}$ & $3.58 \times 10^{3}$ & $3.07 \times 10^{3}$ \\
\hline E10 & 23.36 & 23.65 & 23.505 & 0.205 & $3.48 \times 10^{4}$ & $2.85 \times 10^{4}$ & $3.17 \times 10^{4}$ & $1.62 \times 10^{5}$ \\
\hline E11 & 20.76 & 20.74 & 20.73 & 0.014 & $2.06 \times 10^{5}$ & $2.08 \times 10^{5}$ & $2.07 \times 10^{5}$ & $5.18 \times 10^{5}$ \\
\hline E12 & 22.48 & 22.08 & 22.28 & 0.283 & $6.37 \times 10^{4}$ & $8.33 \times 10^{4}$ & $7.35 \times 10^{4}$ & $1.91 \times 10^{5}$ \\
\hline E13 & 16.22 & 15.60 & 15.91 & 0.438 & $4.57 \times 10^{6}$ & $6.99 \times 10^{6}$ & $5.78 \times 10^{6}$ & $4.08 \times 10^{7}$ \\
\hline E14 & 16.92 & 21.17 & 19.05 & 3.005 & $3.38 \times 10^{7}$ & $1.56 \times 10^{5}$ & $1.70 \times 10^{7}$ & $7.78 \times 10^{7}$ \\
\hline E15 & 32.60 & 31.65 & 32.125 & 0.672 & $6.35 \times 10^{1}$ & $1.21 \times 10^{2}$ & $9.23 \times 10^{1}$ & $3.31 \times 10^{2}$ \\
\hline E16 & 23.96 & 23.34 & 23.65 & 0.438 & $2.32 \times 10^{4}$ & $3.54 \times 10^{4}$ & $2.87 \times 10^{4}$ & $1.28 \times 10^{5}$ \\
\hline E17 & 12.21 & 12.53 & 12.27 & 0.226 & $7.06 \times 10^{7}$ & $5.67 \times 10^{7}$ & $6.78 \times 10^{7}$ & $7.53 \times 10^{8}$ \\
\hline E18 & 23.23 & 23.73 & 23.48 & 0.354 & $3.82 \times 10^{4}$ & $2.71 \times 10^{4}$ & $3.22 \times 10^{4}$ & $1.72 \times 10^{5}$ \\
\hline E19 & 12.05 & 12.69 & 12.37 & 0.453 & $7.87 \times 10^{7}$ & $5.09 \times 10^{7}$ & $6.33 \times 10^{7}$ & $8.44 \times 10^{8}$ \\
\hline E20 & 15.44 & 15.20 & 15.32 & 0.170 & $7.78 \times 10^{6}$ & $9.17 \times 10^{6}$ & $8.45 \times 10^{6}$ & $6.34 \times 10^{7}$ \\
\hline E21 & 12.00 & 11.26 & 11.63 & 0.523 & $8.15 \times 10^{7}$ & $1.35 \times 10^{8}$ & $1.05 \times 10^{8}$ & $1.09 \times 10^{9}$ \\
\hline E22 & 19.88 & 19.38 & 19.63 & 0.354 & $3.75 \times 10^{5}$ & $5.29 \times 10^{5}$ & $4.46 \times 10^{5}$ & $2.94 \times 10^{6}$ \\
\hline E23 & 12.02 & 12.42 & 12.22 & 0.283 & $8.04 \times 10^{7}$ & $6.12 \times 10^{7}$ & $7.01 \times 10^{7}$ & $5.01 \times 10^{8}$ \\
\hline E24 & 21.95 & 22.39 & 22.17 & 0.311 & $9.14 \times 10^{4}$ & $6.77 \times 10^{4}$ & $7.87 \times 10^{4}$ & $6.75 \times 10^{4}$ \\
\hline E25 & 26.40 & 26.82 & 26.61 & 0.297 & $4.38 \times 10^{3}$ & $3.29 \times 10^{3}$ & $3.80 \times 10^{3}$ & $1.95 \times 10^{4}$ \\
\hline E26 & 16.02 & 16.86 & 16.44 & 0.594 & $5.24 \times 10^{6}$ & $2.95 \times 10^{6}$ & $3.93 \times 10^{6}$ & $9.83 \times 10^{6}$ \\
\hline E27 & 12.25 & 11.79 & 12.02 & 0.325 & $6.87 \times 10^{7}$ & $9.40 \times 10^{7}$ & $8.04 \times 10^{7}$ & $2.09 \times 10^{8}$ \\
\hline E28 & 18.40 & 16.44 & 17.42 & 1.386 & $1.03 \times 10^{6}$ & $3.93 \times 10^{6}$ & $2.01 \times 10^{6}$ & $1.42 \times 10^{7}$ \\
\hline E29 & 17.10 & 16.74 & 16.92 & 0.255 & $2.51 \times 10^{6}$ & $3.20 \times 10^{6}$ & $2.83 \times 10^{6}$ & $1.30 \times 10^{7}$ \\
\hline E30 & 16.70 & 16.24 & 16.47 & 0.325 & $3.29 \times 10^{6}$ & $4.51 \times 10^{6}$ & $3.85 \times 10^{6}$ & $1.38 \times 10^{7}$ \\
\hline
\end{tabular}
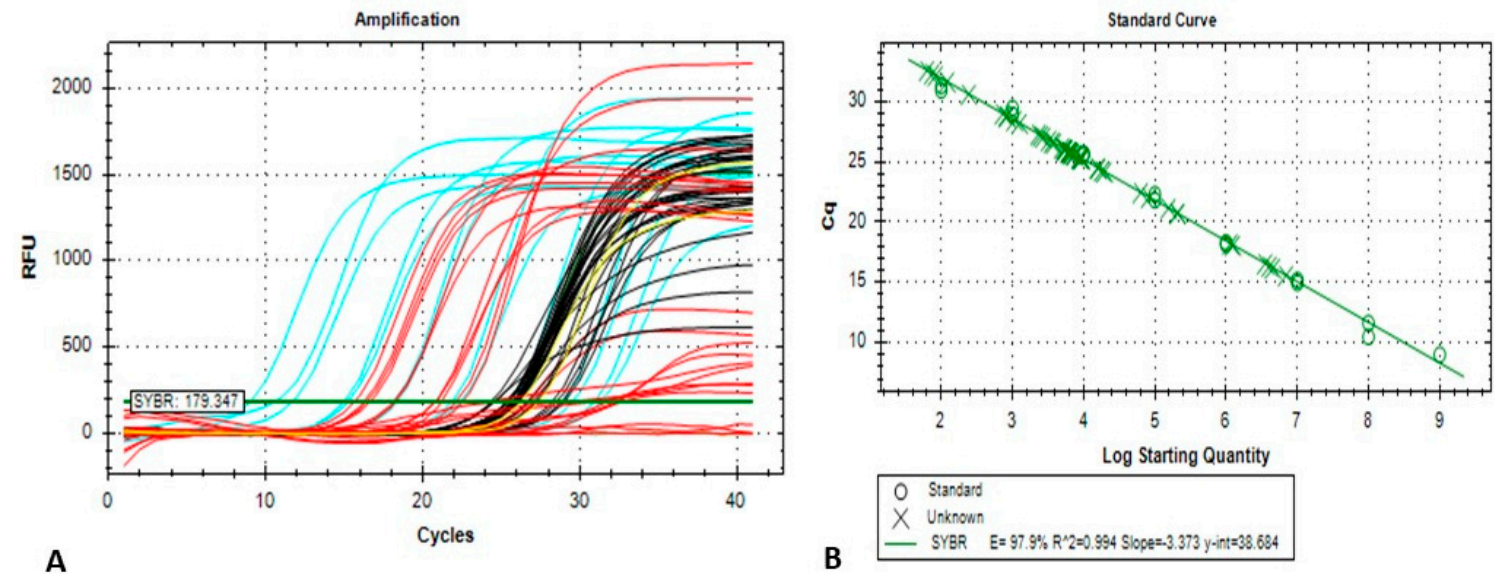

Figure 8. (A) Amplification curves targeting VP28 of WSSV and (B) standard curve produced using quantitative real-time PCR. Plasmid samples with known concentrations were used to obtain the standard curve, and copy numbers of unknown samples were calculated comparing Cycle Threshold $\left(C_{T}\right)$ values of samples and standards. 


\subsection{Crab Mortality Rates and Viral Load Counts Differed in Treated Crabs}

The LT50 and LT100 for infected crabs varied among the treatments, while no crab died in the control group. The experiment was run till 62 days post infection (dpi) as long as all crabs died in the experimental groups challenged with both phylotypes (BD1 and BD2) (Figures 9 and S4). The LT50 and LT100 were 31 and 48 dpi in BD1-challenged crabs, and LT50 and LT100 were 40 and $62 \mathrm{dpi}$ for BD2-challenged crabs, respectively. The mean viral loads in the crabs challenged with BD1 and BD2 were $12.06 \pm 0.48$ and $9.95 \pm 0.37$ per g of tissue, respectively (Figure 10, Table S2).

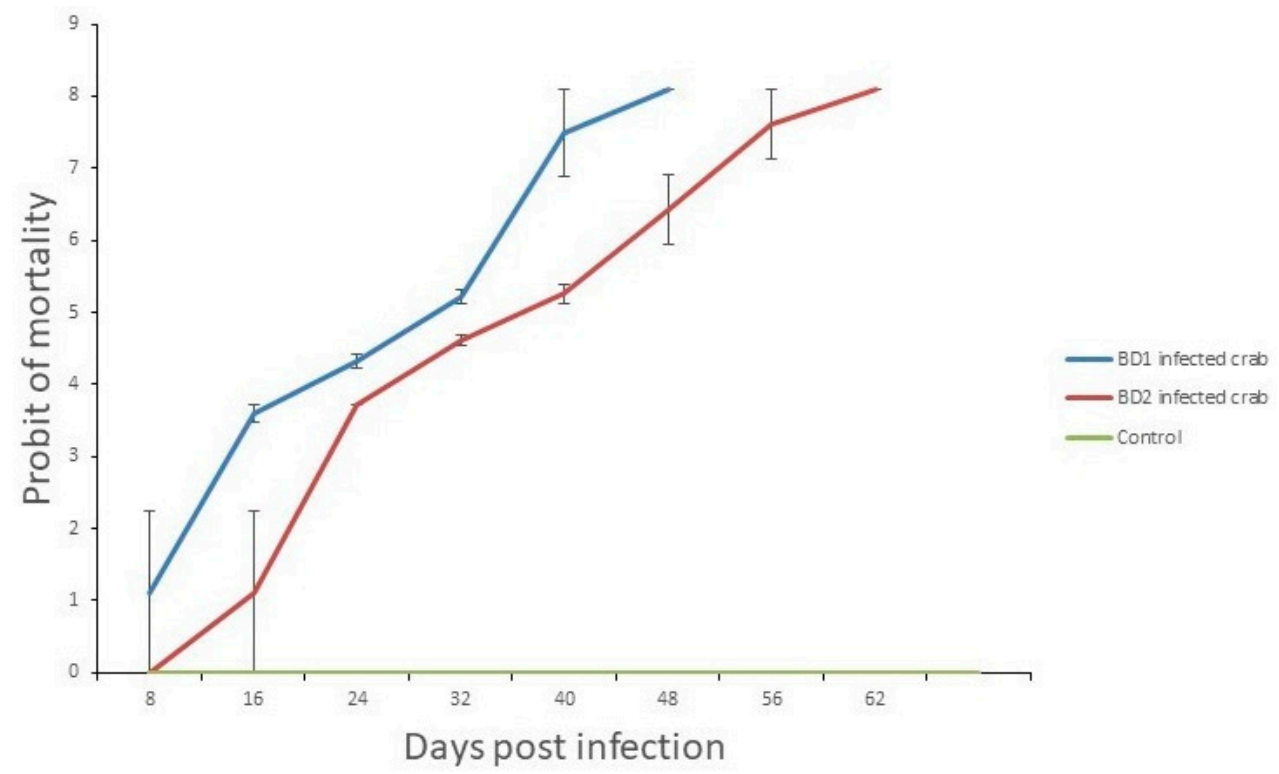

Figure 9. Probit of crab mortality after infection with ingestion method using a dose prepared from BD1- and BD2-infected crab tissue, and control (WSSV-negative crab tissue). The $Y$-axis represents the morality rates, while the $X$-axis shows the days of post challenge.

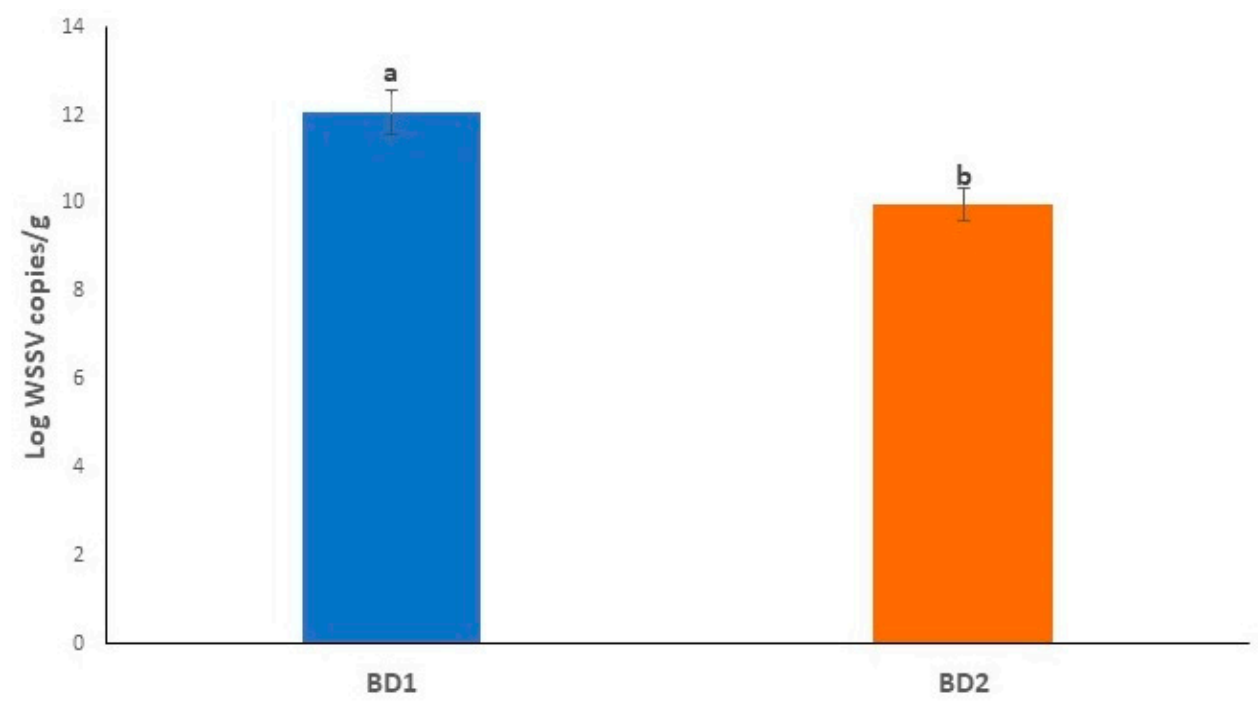

Figure 10. Log WSSV copies per gram tissue of infected crabs of both groups and control. Error bars and 'alphabets' represent standard deviation and significant difference $(p<0.05)$, respectively.

\subsection{Gene Expression Profiling of Immunity Genes in Both the Infected Groups}

In the current study, two important immunity genes of shrimps, penaeidin and lysozyme, were considered for expression analysis, both of which are antimicrobial peptides (AMPs). Gene expression was observed after 73 hpi in this immersion challenge 
study. Figure 11 provides the average relative expression of penaeidin and lysozyme after exposure of shrimp PL to both the circulating phylotypes showing comparatively higher expression of lysozyme than penaeidin in both groups. While comparing the expression in the challenged groups, it was found that average relative expressions of these two genes were lower in BD1-challenged PL than in BD2-challenged PL (Figure 11).

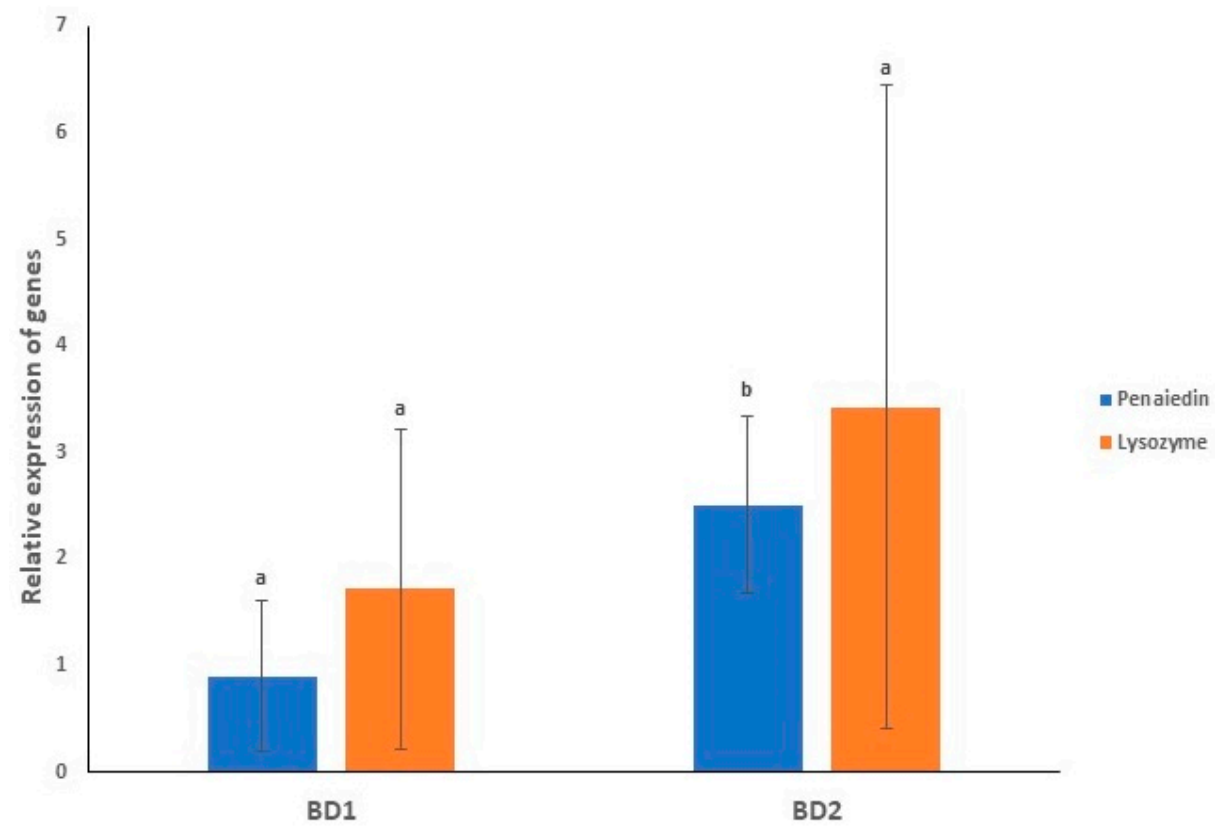

Figure 11. Average relative expression of immunity genes (Penaeidin and lysozyme) in shrimp PL after exposure to WSSV. Error bars and 'alphabets' represent standard error of means and significant differences between the expression of immunity genes, respectively.

\subsection{Rab7-VP28 Binding Affinity}

In the present study, the lower Kd value was observed for the binding of VP28 with glutamic acid at the 167 th position $\left(1.6 \times 10^{-8}\right)$ than the other mutated one with glycine on that position $\left(5.1 \times 10^{-8}\right)$. The higher the $\mathrm{Kd}$ value, the lower may be the strength of binding between proteins (Figure S5). From this in silico approach towards getting the binding affinity in two different complexes, it was predicted that the BD1 might have more chance to bind with the receptor protein Rab7 of P. monodon. Moreover, prediction results from DynaMut showed an increase in molecular flexibility instead of rigidification in VP28 of BD2 through analysing the difference in vibrational entropy $(\Delta \Delta \mathrm{SVib}$ ENCoM: $0.030 \mathrm{kcal} \cdot \mathrm{mol}^{-1} \cdot \mathrm{K}^{-1}$ ) (Figure S5).

\section{Discussion}

Penaeus monodon is considered as one of the most valuable commercially cultured aquatic species in Bangladesh. This crustacean species has been badly affected by WSSV in all shrimp-producing countries across Asia, including Bangladesh [20,52]. In this study, the prevalence of WSSV infections in crustacean populations (shrimps and crabs) varied in study areas, keeping significantly higher prevalence of this disease both in shrimp ghers of the Cox's Bazar district compared to Satkhira. Compared to the shrimp population, the WSSV detection rate in crabs remained much lower, which might be associated with their disease tolerance capacity and carrier status [9]. Unlike shrimps, mud crabs are generally believed to be highly tolerant to WSSV and keep being infected for longer periods without symptoms of disease. In this study, the WSSV-positive crabs were found in those ghers only where the shrimps were also WSSV-positive. Rouf et al. reported in their study that the mud crab species found in the coastal regions of Bangladesh was Scylla olivacea [53]. They confirmed it by genetic analysis of the partial sequences of one mitochondrial gene, $12 \mathrm{~S}$ 
rRNA, as well as through studying their morphological characteristics and morphometric ratios. However, if $P$. monodon and Scylla spp. are co-cultured, shrimps may become more vulnerable to WSSV infection because shrimps can be infected through horizontal transmission of the virus from the crabs [54]. Thus, it is very important to study regularly whether these shrimps are becoming diseased from horizontal gene transfer from carrier crabs to control WSSV infections from shrimp ghers and eradicating the disease sources. In a previous study, Hossain et al. reported higher prevalence of WSSV infections in the shrimp ghers of the Satkhira district of Bangladesh [20]. The prevalence of WSSV was $23 \%$ in the wild captured crustaceans from the south-west and south-east coast of India which included Scylla serrata, Squilla mantis, Penaeus indicus, and Metapenaeus spp. [55]. The physicochemical parameter analysis revealed that $P$. monodon can survive in a wide range of salinity (13-21 ppt), $\mathrm{pH}$ (7.8-9.1), dissolved oxygen (2.61-6.06 ppm), temperature $\left(28.7-34^{\circ} \mathrm{C}\right)$. Therefore, temperature and salinity were found to be changed very little, both in WSSV-positive and WSSV-negative shrimp ghers. In a previous study, it was found that the acceptable range of salinity, $\mathrm{pH}$, dissolved oxygen and temperature can be $15-25 \mathrm{ppt}$, $\mathrm{pH}$ 7.5-8.5, dissolved oxygen more than $4 \mathrm{ppm}$ and temperature $28-32{ }^{\circ} \mathrm{C}$, corroborating our results [6]. We found a significant association between increase in temperature and decrease in salinity with the presence of WSSV in shrimp ghers of both Cox's Bazar and Satkhira districts. In this study, dissolved oxygen values also had a significant association in the prevalence of WSSV. Frequent fluctuations in physicochemical factors such as $\mathrm{pH}$, temperature, and dissolved oxygen make shrimps susceptible to stress, which ultimately can lead to disease [56,57]. Several lines of evidence suggested that temperature and salinity play a very important role in WSSV infection affecting the immune response of the crustaceans [57,58].

In the current study, shrimp and crab samples had huge viral loads in tissue. Remarkably, WSSV Log load per gram of shrimp and crab tissues remained much higher in samples of Satkhira district compared to Cox's Bazar. However, comparing the viral load counts in both shrimp and crab samples, we did not find any significant difference. The presence of such high viral load risks all the shrimps in the ghers as well as the adjacent ghers, creating a possibility for WSSV outbreak in the whole area. This study suggests that WSSV load determination is essential because a shift in temperature due to any environmental reason can lead to outbreak if there is even lightly WSSV-infected crustaceans in the water body [59]. Siddique et al. reported that if few shrimps in a gher are infected with WSSV, other shrimps might be exposed over ingestion or immersion, resulting in a rapid spread of the disease leading to production disaster [29].

Phylogenetic analysis showed that VP28 sequences of Bangladesh and India fell into the major clades (phylotype BD1 and BD2). In Bangladesh, the isolated viruses showed genetic divergence falling under two different clusters (BD1 and BD2). These different clusters consisted of WSSV samples from other countries, including India, China, South Korea and Vietnam. In this study, the VP28 isolates (MZ383195- MZ383198) sequenced in 2018 (BD2 phylogroup) showed the closest genetic relatedness with previously reported VP28 isolates of Bangladesh sequenced in 2014 [20]. Likewise, two VP28 isolates (MZ383193MZ383194) sequenced in 2019 (BD1 phylogroup) showed the closest ancestral relation to six VP28 isolates sequenced in 2015 and 2017 from Bangladesh and two Indian isolates. Thus, from the phylogenetic tree, it can be assumed that all of the isolates sequenced in the present study (2018 and 2019) were quite closely related to the VP28 sequences reported from Bangladesh in the previous years (2011-2017), and the result correlates with the previous works $[20,29]$.

VP28 is one of the most important structural proteins of WSSV responsible for systemic infection and found to be crucial in cell recognition, attaching and penetration into the shrimp cells [60]. The aa mutation analysis showed that majority of VP28 sequences (64\%) of the WSSV reported from different geographical locations (including the seven sequences of the current study) underwent mutations at 21 positions. Several earlier studies from Bangladesh $[20,29]$ and neighbouring countries $[61,62]$ also reported aa variations in VP28 
of WSSV, supporting our current findings. In addition, residue position 167 showed glycine instead of glutamic acid $(\mathrm{E} \rightarrow \mathrm{G})$ in Bangladeshi and Egyptian VP28 sequences. In both shrimp and crab isolates from the Satkhira district of Bangladesh, the unique mutation $(\mathrm{E} \rightarrow \mathrm{G})$ at position 167 that falls between two beta strands of protein are thought to be involved in receptor recognition $[29,62]$. The exclusive aa mutation at residue position 167 of VP28 were also reported in the isolates of Bangladesh collected in 2014, 2015 and 2018 [20,29]. VP28 fuses with the host protein (PmRab7), which is the beginning of the virushost relationship, and the viral nucleocapsid is then transported to the nucleus of host cell where the replication of the viral genome starts [62]. Sritunyalucksana et al. first mentioned that the Rab7 protein of penaeid shrimp is involved in binding an envelope protein of WSSV known as VP28 [63]. Our prediction results using DynaMut for molecule flexibility analysis had the impression that there could be rigidification in binding interactions for VP28 of BD1, and also generated a sense of possibility of stronger binding affinity with the VP28 of BD1. Kd values help to presume that there could be higher binding affinity in Rab7-VP28 complex when shrimps are infected with the BD1 phylotype. As transgenically engineered VP28 had been used in studies to build innate immunity in shrimp for its capacity to localize on host epithelial cells and attention has been given to drug designing using molecular docking and simulation studies [64], the role of mutations in VP28 are crucial to be reflected upon.

Infection assay of shrimp PL with dilution containing $10^{8}$ WSSV showed $97 \%$ mortality rates at $96 \mathrm{~h}$ of challenge irrespective of challenge with any group. Mortality patterns of PL also showed variation when exposed to different loads when challenged with both groups of WSSV. The onset of death and lethal time 50 (LT50) in the experimental PL was found inversely proportional to the dilution stock (earlier death time with less diluted stock). The mean LT50 values for the challenged PL differed between the phylogroups (BD1 and BD2) of WSSV, and remained higher in BD2-challenged shrimp PL. The average median LT50 remained lower in the case of BD1-challenged shrimp PL. Mean Log viral copy numbers were found to differ between both groups challenged PL, staying statistically higher (6.47 per mg tissue) in BD1-treated PL. Mud crabs were found to be carriers and vectors of WSSV in different countries and used for virus infectivity experiments in studies [41,42]. In our study, crabs were infected through ingestion, and it was found that crabs infected with BD1 died earlier than the ones challenged with BD2. The viral loads in all infected samples showed higher copy numbers in BD1-challenged crabs, such as BD1-challenged PL. The differences in viral load have also been stated by other authors $[65,66]$ and can possibly be elucidated by differences in the degree of virus replication, physiological state, and defense response of the host. Higher WSSV copies and lower Ct values in BD1-challenged samples indicated that this phylotype of WSSV might contain more virus copies at the later stage of infection. There are indications that susceptibility to WSSV may differ between life stages, species and different decapods [67,68]; however, the use of a known dose of different phylotypes of WSSV is critical to demonstrate these differences. An immersion challenge to shrimp PL with an inoculum of known virus content showed that a minimum of five logs of WSSV copies is necessary to establish disease and produced a LT50 of $52 \mathrm{~h}$ [68]. The ingestion method for crab infections was followed in the study of Gunasekaran et al. [42] who reported that in case of crabs, the ingestion method resulted in faster deaths than the water-borne method. Although shrimps and crabs were challenged using two different methods of infection, crabs died later in our study. This may be because the crabs are a hardy species and carry the virus for a long time, and on the other hand, shrimps die quickly within 3-10 days after infection, and it is also of utmost important to consider that we infected the post larvae of shrimps which are not so resilient to diseases as those in early stage of life. Cumulative mortality was observed in shrimp infection assays using immersion or per os inoculation to be $100 \%$ at $108 \mathrm{hpi}$ with different doses and the LT50 of low to high doses were 65, 57 and 50 hpi in a study conducted by Escobedo-Bonilla et al. [10].

Gene expression profiling of penaeidin and lysozyme was performed to support the findings of infection assays of the current study. Penaeidin is an antimicrobial peptide 
explicitly observed in penaeid shrimp. which are commonly known to show antibacterial and antifungal actions, and was reported to perform a potential part in antiviral immunity of shrimps exposed to WSSV [69]. It was observed that in P. monodon PL-challenged groups, there was a differential pattern of gene expression, which suggested that transcription could be due to two stages of protection mechanism, killing of microorganisms and wound healing [70-74]. Penaeidin's C-terminal cysteine-rich domain with its amphipathic shape may perform as the domain for the binding pathogen. Lysozyme is another important AMP that is involved in the host-resistance arrangement of invading microorganisms [75-77]. In a previous study with blue shrimp (Litopenaeus stylirostris), lysozyme was found to be upregulated in WSSV-infected shrimp, suggesting its involvement in the innate immune response of shrimp to WSSV [78]. In the current study, the average relative gene expressions of penaedin and lysozyme in both infected groups expressed at a low level in the BD1challenged PL with $100 \%$ mortality were quicker at producing more virus copies.

\section{Conclusions}

The current study investigated the prevalence and virulence properties of circulating WSSV in Bangladesh. The prevalence of WSSV was found to differ significantly according to hosts (i.e., shrimp and crabs), geographic locations of the ghers (Cox's Bazar vs. Satkhira districts), and also during the time periods (2017 to 2019). The in vivo infection assay of the shrimp PL with BD1 phylotype showed an earlier LT50 and LT100 and higher viral load compared to those challenged with BD2. The AMP, penaeidin and lysozyme expression was lower in the BD1-challenged group compared to BD2. The findings of the present study revealed that the relative virulence properties of the WSSV could vary depending on the VP28 gene-based phylotypes (BD1 > BD2). Extensive investigation on the prevalence of WSSV throughout the country recruiting a larger sample group and geoclimatic conditions could illustrate more about the occurrence of this deadly virus in the semi-intensive and improved traditional ghers of Bangladesh. Moreover, changes or fluctuations in different physicochemical parameters are crucial to be observed regularly in the ghers, which could be important factors related to WSSV infection, and to understand the vibrant biological systems of host crustaceans infected with different groups of WSSV. Although it is still early to draw a conclusion on the virulence of these phylotypes, the results of the present study would be worthwhile for taking precautions in shrimp farms against WSSV and may shed new light to mitigate the huge economic loss every year in the shrimp farming of Bangladesh.

Supplementary Materials: The following supporting information can be downloaded at: https: / / www.mdpi.com/article/10.3390/microorganisms10010191/s1. Figure S1: A. Lane 2: positive shrimp sample from Satkhira, lane 3: positive shrimp sample from Cox's Bazar, lane 4: positive Scylla olivacea sample from Satkhira, lane 5: positive Scylla olivacea sample from Cox's Bazar, lane 6: positive control, lane 7: (Negative control) sample in which WSSV was not detected; B. 148 bp products represent detection confirmation in real-time PCR products from both challenged groups (E and $\mathrm{G}$ represent samples of BD1 and BD2, respectively); C. Lane 2-3: Samples from control group showing no band, lane 4: No template control, lane 5-14: Challenged PL positive in conventional PCR, and lane 15: positive control (Lane 1s in A, B and C represent 100 bp ladder). Figure S2: Major mutations of VP28 reported from different countries and hosts (our sequences and previously published sequences downloaded from NCBI were used for the analysis). Figure S3: VP28 sequences retrieved from previously published whole genome sequences used for making phylogenetic tree using Geneious Prime Trial version 2020. Figure S4: Lane 1: 100 bp ladder, lane 2-11: infected crabs after exposure to WSSV, and lane 12: crab from control group (no band in the control confirmed samples of other lanes showing bands were positive). Figure S5: A. Glycine to Glutamic Acid signifies rigidification and B. Glutamic Acid to Glycine at 167th amino acid position signifies gaining flexibility using DynaMut web server. 'Blue' signifies a rigidification of the structure (G167E) (Figure S5A) and 'Red' represents a gain in flexibility (E167G) (Figure S5B). Table S1: Physicochemical parameters in the shrimp ponds when no WSSV was reported in the areas. Table S2: $\mathrm{C}_{\mathrm{T}}$ values and mean WSSV 
copies from the quantitative real-time PCR of crab ingestion challenge pilot experiment (E and G prefixes of Sample IDs represent samples challenged with BD1 and BD2).

Author Contributions: M.M.H. carried out the studies (sampling, laboratory experiments, molecular study and data analysis), and drafted the initial manuscript. M.N.H. critically interpreted the results, produced some of the figures, and edited the manuscript. F.A. and M.I.-M.H. helped in sample collection, sample preparation, laboratory experiments and drafting the initial manuscript. M.S. and M.A.H. developed the hypothesis, supervised the work, and critically reviewed the final manuscript. All authors have read and agreed to the published version of the manuscript.

Funding: This research received no external funding.

Data Availability Statement: The reported WSSV sequences of this study have been submitted to the GenBank database under the accession numbers MZ383193 to MZ383199.

Acknowledgments: The first author of this manuscript, $\mathrm{MMH}$, received his $\mathrm{PhD}$ Fellowship from the Bangabandhu Science and Technology Fellowship Trust, Ministry of Science and Technology, Government of the People's republic of Bangladesh. We also acknowledge the cooperation of the shrimp farmers for allowing us to conduct the study. Sincere thanks to Anwar Hossain, Department of Fisheries, University of Dhaka, Mohammad Anwar Siddique, Department of Microbiology, University of Dhaka and Md. Shaminur Rahman, Department of Microbiology, Jashore University of Science and Technology for their support in this study.

Conflicts of Interest: The authors declare no conflict of interest.

\section{References}

1. Nisar, U.; Zhang, H.; Navghan, M.; Zhu, Y.; Mu, Y. Comparative analysis of profitability and resource use efficiency between Penaeus monodon and Litopenaeus vannamei in India. PLoS ONE 2021, 16, e250727. [CrossRef]

2. Trang, T.T.; Hung, N.H.; Ninh, N.H.; Knibb, W.; Nguyen, N.H. Genetic variation in disease resistance against White Spot Syndrome Virus (WSSV) in Liptopenaeus vannamei. Front. Genet. 2019, 10, 264. [CrossRef]

3. Rahman, M.; Hossain, M. Production and export of shrimp of Bangladesh: Problems and prospects. Progress. Agric. 2009, 20, 163-171. [CrossRef]

4. DoF. National Fish Week Compendium 2013; Ministry of Fisheries and Livestock, People's Republic of Bangladesh, DoF: Dhaka, Bangladesh, 2013. (In Bengali)

5. FRSS. Fisheries Statistical Yearbook of Bangladesh; Fisheries Resources Survey System (FRSS), Department of Fisheries: Dhaka, Bangladesh, 2017.

6. Tendencia, E.A.; Verreth, J.A. Temperature fluctuation, low salinity, water microflora: Risk factors for WSSV outbreaks in Penaeus monodon. Isr. J. Aquac.-Bamidgeh 2011, 63, 1-7.

7. de la Luz Vazquez-Sauceda, M.; Sánchez-Martínez, J.G.; Pérez-Castañeda, R.; Rábago-Castro, J.L.; Aguirre-Guzmán, G.; Vargas-Cruz, D.Y. White Spot Syndrome Virus (WSSV) and Necrotizing Hepatopancreatitis (NHP) detection in wild shrimpof the San Andrés Lagoon, Mexico. Rev. Biol. Mar. Oceanogr. 2016, 51, 455-459. [CrossRef]

8. Zhang, X.; Zeng, X.; Sun, Y.; Wang, Y.; Zhang, Z. Enhanced Immune Protection of Mud Crab Scylla paramamosain in Response to the Secondary Challenge by Vibrio parahaemolyticus. Front. Immunol. 2020, 11, 565958. [CrossRef]

9. Molla, M.; Islam, M.; Islam, S.; Salam, M. Socio-economic status of crab collectors and fatteners in the southwest region of Bangladesh. J. Bangladesh Agric. Univ. 2009, 7, 411-419. [CrossRef]

10. Escobedo-Bonilla, C.M.; Alday-Sanz, V.; Wille, M.; Sorgeloos, P.; Pensaert, M.; Nauwynck, H. A review on the morphology, molecular characterization, morphogenesis and pathogenesis of white spot syndrome virus. J. Fish Dis. 2008, 31, 1-18. [CrossRef]

11. Somboonna, N.; Mangkalanan, S.; Udompetcharaporn, A.; Krittanai, C.; Sritunyalucksana, K.; Flegel, T. Mud crab susceptibility to disease from white spot syndrome virus is species-dependent. BMC Res. Notes 2010, 3, 315. [CrossRef]

12. Sánchez-Paz, A. White spot syndrome virus: An overview on an emergent concern. Vet. Res. 2010, 41, 43. [CrossRef]

13. Gong, Y.; Kong, T.; Ren, X.; Chen, J.; Lin, S.; Zhang, Y.; Li, S. Exosome-mediated apoptosis pathway during WSSV infection in crustacean mud crab. PLoS Pathog. 2020, 16, e1008366. [CrossRef]

14. Zhu, G.; Li, S.; Wu, J.; Li, F.; Zhao, X.-M. Identification of functional gene modules associated with STAT-mediated antiviral responses to white spot syndrome virus in shrimp. Front. Physiol. 2019, 10, 212. [CrossRef]

15. Yu, Y.; Liu, J.; Li, F.; Zhang, X.; Zhang, C.; Xiang, J. Gene set based association analyses for the WSSV resistance of Pacific white shrimp Litopenaeus vannamei. Sci. Rep. 2017, 7, 40549. [CrossRef]

16. Corbel, V.; Zuprizal, Z.; Shi, C.; Arcier, J.M.; Bonami, J.R. Experimental infection of European crustaceans with white spot syndrome virus (WSSV). J. Fish Dis. 2001, 24, 377-382. [CrossRef]

17. Sun, Y.; Li, F.; Sun, Z.; Zhang, X.; Li, S.; Zhang, C.; Xiang, J. Transcriptome analysis of the initial stage of acute WSSV infection caused by temperature change. PLOS ONE 2014, 9, e90732. 
18. Xie, S.; Zhang, X.; Zhang, J.; Li, F.; Xiang, J. Envelope proteins of white spot syndrome virus (WSSV) interact with Litopenaeus vannamei peritrophin-like protein (LvPT). PLoS ONE 2015, 10, e0144922. [CrossRef]

19. Kwang, J. Oral vaccination of baculovirus-expressed VP28 displays enhanced protection against white spot syndrome virus in Penaeus monodon. PLoS ONE 2011, 6, e26428.

20. Hossain, A.; Nandi, S.; Siddique, M.; Sanyal, S.; Sultana, M.; Hossain, M. Prevalence and distribution of W hite S pot S yndrome V irus in cultured shrimp. Lett. Appl. Microbiol. 2015, 60, 128-134. [CrossRef] [PubMed]

21. Tsai, J.-M.; Wang, H.-C.; Leu, J.-H.; Hsiao, H.-H.; Wang, A.H.-J.; Kou, G.-H.; Lo, C.-F. Genomic and proteomic analysis of thirty-nine structural proteins of shrimp white spot syndrome virus. J. Virol. 2004, 78, 11360-11370. [CrossRef]

22. Sarathi, M.; Simon, M.C.; Ahmed, V.I.; Kumar, S.R.; Hameed, A.S. Silencing VP28 gene of white spot syndrome virus of shrimp by bacterially expressed dsRNA. Mar. Biotechnol. 2008, 10, 198. [CrossRef]

23. Musthaq, S.S.; Madhan, S.; Hameed, A.S.; Kwang, J. Localization of VP28 on the baculovirus envelope and its immunogenicity against white spot syndrome virus in Penaeus monodon. Virology 2009, 391, 315-324. [CrossRef]

24. Verbruggen, B.; Bickley, L.K.; Van Aerle, R.; Bateman, K.S.; Stentiford, G.D.; Santos, E.M.; Tyler, C.R. Molecular mechanisms of white spot syndrome virus infection and perspectives on treatments. Viruses 2016, 8, 23. [CrossRef]

25. Nilsen, P.; Karlsen, M.; Sritunyalucksana, K.; Thitamadee, S. White spot syndrome virus VP28 specific double-stranded RNA provides protection through a highly focused siRNA population. Sci. Rep. 2017, 7, 1028. [CrossRef]

26. Zwart, M.P.; Dieu, B.T.M.; Hemerik, L.; Vlak, J.M. Evolutionary trajectory of white spot syndrome virus (WSSV) genome shrinkage during spread in Asia. PLoS ONE 2010, 5, e13400. [CrossRef]

27. Parrilla-Taylor, D.P.; Vibanco-Pérez, N.; Durán-Avelar, M.D.J.; Gomez-Gil, B.; Llera-Herrera, R.; Vázquez-Juárez, R. Molecular variability and genetic structure of white spot syndrome virus strains from northwest Mexico based on the analysis of genomes. FEMS Microbiol. Lett. 2018, 365, fny216. [CrossRef]

28. Joseph, T.C.; Rajan, L.A.; James, R.; Lalitha, K.; Surendran, P. Variations of structural protein sequences among geographical isolates of white spot syndrome virus. Int. Aquat. Res. 2015, 7, 85-91. [CrossRef]

29. Siddique, M.A.; Haque, M.I.-M.; Sanyal, S.K.; Hossain, A.; Nandi, S.P.; Alam, A.R.U.; Sultana, M.; Hasan, M.; Hossain, M.A Circulatory white spot syndrome virus in South-West region of Bangladesh from 2014 to 2017: Molecular characterization and genetic variation. AMB Express 2018, 8, 25. [CrossRef]

30. Rout, N.; Kumar, S.; Jaganmohan, S.; Murugan, V. DNA vaccines encoding viral envelope proteins confer protective immunity against WSSV in black tiger shrimp. Vaccine 2007, 25, 2778-2786. [CrossRef]

31. Mendoza-Cano, F.; Sánchez-Paz, A. Development and validation of a quantitative real-time polymerase chain assay for universal detection of the White Spot Syndrome Virus in marine crustaceans. Virol. J. 2013, 10, 186. [CrossRef]

32. Rahman, M.S.; Islam, M.R.; Hoque, M.N.; Alam, A.S.M.R.U.; Akther, M.; Puspo, J.A.; Akter, S.; Anwar, A.; Sultana, M.; Hossain, M.A. Comprehensive annotations of the mutational spectra of SARS-CoV-2 spike protein: A fast and accurate pipeline. Transbound. Emerg. Dis. 2020, 68, 1625-1638. [CrossRef]

33. Benson, D.A.; Cavanaugh, M.; Clark, K.; Karsch-Mizrachi, I.; Lipman, D.J.; Ostell, J.; Sayers, E.W. GenBank. Nucleic Acids Res. 2016, 45, D37-D42. [CrossRef]

34. Altschul, S.F.; Gish, W.; Miller, W.; Myers, E.W.; Lipman, D.J. Basic local alignment search tool. J. Mol. Biol. 1990, 215, 403-410. [CrossRef]

35. Kumar, S.; Stecher, G.; Tamura, K. MEGA7: Molecular evolutionary genetics analysis version 7.0 for bigger datasets. Mol. Biol. Evol. 2016, 33, 1870-1874. [CrossRef]

36. Saha, O.; Rakhi, N.N.; Hoque, M.N.; Sultana, M.; Hossain, M.A. Genome-wide genetic marker analysis and genotyping of Escherichia fergusonii strain OTSVEF-60. Braz. J. Microbiol. 2021, 52, 989-1004. [CrossRef]

37. Hoque, M.N.; Istiaq, A.; Clement, R.A.; Gibson, K.M.; Saha, O.; Islam, O.K.; Abir, R.A.; Sultana, M.; Siddiki, A.; Crandall, K.A. Insights into the resistome of bovine clinical mastitis microbiome, a key factor in disease complication. Front. Microbiol. 2020, 11, 860. [CrossRef]

38. Katoh, K.; Asimenos, G.; Toh, H. Multiple alignment of DNA sequences with MAFFT. In Bioinformatics for DNA Sequence Analysis; Springer: Berlin/Heidelberg, Germany, 2009; pp. 39-64.

39. Rahman, M.S.; Islam, M.R.; Alam, A.R.U.; Islam, I.; Hoque, M.N.; Akter, S.; Rahaman, M.M.; Sultana, M.; Hossain, M.A Evolutionary dynamics of SARS-CoV-2 nucleocapsid protein and its consequences. J. Med. Virol. 2021, 93, 2177-2195. [CrossRef] [PubMed]

40. Rahman, M.S.; Hoque, M.N.; Islam, M.R.; Islam, I.; Mishu, I.D.; Rahaman, M.M.; Sultana, M.; Hossain, M.A. Mutational insights into the envelope protein of SARS-CoV-2. Gene Rep. 2021, 22, 100997. [CrossRef] [PubMed]

41. Chen, L.-L.; Lo, C.-F.; Chiu, Y.-L.; Chang, C.-F.; Kou, G.-H. Natural and experimental infection of white spot syndrome virus (WSSV) in benthic larvae of mud crab Scylla serrata. Dis. Aquat. Org. 2000, 40, 157-161. [CrossRef] [PubMed]

42. Gunasekaran, T.; Gopalakrishnan, A.; Deivasigamani, B.; Seralathan, M.V.; Kathirkaman, P. Spontaneous white spot syndrome virus (WSSV) infection in mud crab (Scylla serrata Forskal 1775) fattening pens farm of south east coast of India. Comp. Clin. Pathol. 2018, 27, 413-419. [CrossRef]

43. Jeena, K.; Prasad, K.P.; Pathan, M.K.; Babu, P.G. Expression profiling of WSSV ORF 199 and shrimp ubiquitin conjugating enzyme in WSSV Infected Penaeus monodon. Asian-Australas. J. Anim. Sci. 2012, 25, 1184. [CrossRef] 
44. $\quad$ Deris, Z.M.; Iehata, S.; Ikhwanuddina, M.; Sahimi, M.B.M.K.; Do, T.D.; Sorgeloos, P.; Sung, Y.Y.; Wong, L.L. Immune and bacterial toxin genes expression in different giant tiger prawn, penaeus monodon post-larvae stages following AHPND-causing strain of vibrio parahaemolyticus challenge. Aquac. Rep. 2020, 16, 100248. [CrossRef]

45. Shekhar, M.S.; Gomathi, A.; Gopikrishna, G.; Ponniah, A.G. Gene expression profiling in gill tissues of White spot syndrome virus infected black tiger shrimp Penaeus monodon by DNA microarray. Virus Dis. 2015, 26, 9-18. [CrossRef] [PubMed]

46. Vangone, A.; Bonvin, A.M.J.J. Contact-based prediction of binding affinity in protein-protein complexes. eLife 2015, 4, e07454. [CrossRef]

47. Xue, L.; Rodrigues, J.; Kastritis, P.; Bonvin, A.M.J.J.; Vangone, A. PRODIGY: A web-server for predicting the binding affinity in protein-protein complexes. Bioinformatics 2016, 32, 3676-3678. [CrossRef] [PubMed]

48. Rahman, M.S.; Hoque, M.N.; Islam, M.R.; Akter, S.; Alam, A.R.U.; Siddique, M.A.; Saha, O.; Rahaman, M.M.; Sultana, M.; Crandall, K.A.; et al. Epitope-based chimeric peptide vaccine design against S, M and E proteins of SARS-CoV-2, the etiologic agent of COVID-19 pandemic: An in silico approach. PeerJ 2020, 8, e9572. [CrossRef]

49. Biasini, M.; Bienert, S.; Waterhouse, A.; Arnold, K.; Studer, G.; Schmidt, T.; Kiefer, F.; Cassarino, T.G.; Bertoni, M.; Bordoli, L.; et al. SWISS-MODEL: Modelling protein tertiary and quaternary structure using evolutionary information. Nucleic Acids Res. 2014, 42, 252-258. [CrossRef] [PubMed]

50. Rodrigues, C.H.M.; Pires, D.E.V.; Ascher, D.B. DynaMut: Predicting the impact of mutations on protein conformation, flexibility and stability. Nucleic Acids Res. 2018, 46, W350-W355. [CrossRef]

51. Hoque, M.N.; Istiaq, A.; Clement, R.A.; Sultana, M.; Crandall, K.A.; Siddiki, A.Z.; Hossain, M.A. Metagenomic deep sequencing reveals association of microbiome signature with functional biases in bovine mastitis. Sci. Rep. 2019, 9, 13536. [CrossRef]

52. Ayub, F.; Sarker, M.Y.; Alam, M.S. Prevalence of white spot syndrome virus infection detected by one-step and nested PCR in selected tiger shrimp (Penaeus monodon) hatcheries. Aquac. Int. 2008, 16, 405-415. [CrossRef]

53. Rouf, M.; Shahriar, S.; Sarower, M.; Ahsan, M. Taxonomic clarification of mud crab species of genus Scylla (Brachyura: Portunidae) available in the Coastal Regions of Bangladesh. Asian Fish. Sci. 2016, 29, 124-136. [CrossRef]

54. Tuyen, N.; Verreth, J.; Vlak, J.; De Jong, M. Horizontal transmission dynamics of White spot syndrome virus by cohabitation trials in juvenile Penaeus monodon and P. vannamei. Prev. Vet. Med. 2014, 117, 286-294. [CrossRef] [PubMed]

55. Vaseeharan, B.; Jayakumar, R.; Ramasamy, P. PCR-based detection of white spot syndrome virus in cultured and captured crustaceans in India. Lett. Appl. Microbiol. 2003, 37, 443-447. [CrossRef]

56. Zafar, M.; Haque, M.; Aziz, M.; Alam, M. Study on water and soil quality parameters of shrimp and prawn farming in the southwest region of Bangladesh. J. Bangladesh Agric. Univ. 2015, 13, 153-160. [CrossRef]

57. Páez-Osuna, F.; Gracia, A.; Flores-Verdugo, F.; Lyle-Fritch, L.P.; Alonso-Rodrıguez, R.; Roque, A.; Ruiz-Fernández, A.C. Shrimp aquaculture development and the environment in the Gulf of California ecoregion. Mar. Pollut. Bull. 2003, 46, 806-815. [CrossRef]

58. Le Moullac, G.; Haffner, P. Environmental factors affecting immune responses in Crustacea. Aquaculture 2000, 191, 121-131. [CrossRef]

59. Soo, T.C.C.; Bhassu, S. Differential STAT gene expressions of Penaeus monodon and Macrobrachium rosenbergii in response to white spot syndrome virus (WSSV) and bacterial infections: Additional insight into genetic variations and transcriptomic highlights PLoS ONE 2021, 16, e0258655. [CrossRef]

60. Chang, Y.-S.; Liu, W.-J.; Lee, C.-C.; Chou, T.-L.; Lee, Y.-T.; Wu, T.-S.; Huang, J.-Y.; Huang, W.-T.; Lee, T.-L.; Kou, G.-H. A 3D model of the membrane protein complex formed by the white spot syndrome virus structural proteins. PLoS ONE 2010, 5, e10718. [CrossRef]

61. Tang, X.; Wu, J.; Sivaraman, J.; Hew, C.L. Crystal structures of major envelope proteins VP26 and VP28 from white spot syndrome virus shed light on their evolutionary relationship. J. Virol. 2007, 81, 6709-6717. [CrossRef]

62. Verma, A.K.; Gupta, S.; Verma, S.; Mishra, A.; Nagpure, N.; Singh, S.P.; Pathak, A.K.; Sarkar, U.K.; Singh, S.P.; Singh, M. Interaction between shrimp and white spot syndrome virus through PmRab7-VP28 complex: An insight using simulation and docking studies. J. Mol. Model. 2013, 19, 1285-1294. [CrossRef]

63. Sritunyalucksana, K.; Wannapapho, W.; Lo, C.F.; Flegel, T.W. PmRab7 is a VP28-binding protein involved in white spot syndrome virus infection in shrimp. J. Virol. 2006, 80, 10734-10742. [CrossRef] [PubMed]

64. Chandrika, S.K.; Puthiyedathu, S.T. Challenges and prospects of Viral Envelope protein VP28-based control strategies to combat white spot syndromevirus in penaeid shrimps: A review. Rev. Aquac. 2021, 13, 734-743. [CrossRef]

65. Durand, S.; Lightner, D. Quantitative real time PCR for the measurement of white spot syndrome virus in shrimp. J. Fish Dis. 2002, 25, 381-389. [CrossRef]

66. Rahman, M.; Corteel, M.; Escobedo-Bonilla, C.M.; Wille, M.; Alday-Sanz, V.; Pensaert, M.; Sorgeloos, P.; Nauwynck, H. Virulence of white spot syndrome virus (WSSV) isolates may be correlated with the degree of replication in gills of Penaeus vannamei juveniles. Dis. Aquat. Org. 2008, 79, 191-198. [CrossRef] [PubMed]

67. Hameed, A.S.; Balasubramanian, G.; Musthaq, S.S.; Yoganandhan, K. Experimental infection of twenty species of Indian marine crabs with white spot syndrome virus (WSSV). Dis. Aquat. Org. 2003, 57, 157-161. [CrossRef] [PubMed]

68. Escobedo-Bonilla, C.M.; Wille, M.; Sanz, V.A.; Sorgeloos, P.; Pensaert, M.; Nauwynck, H. In vivo titration of white spot syndrome virus (WSSV) in specific pathogen-free Litopenaeus vannamei by intramuscular and oral routes. Dis. Aquat. Org. 2005, 66, 163-170. [CrossRef] 
69. Woramongkolchai, N.; Supungul, P.; Tassanakajon, A. The possible role of penaeidin5 from the black tiger shrimp, Penaeus monodon, in protection against viral infection. Dev. Comp. Immunol. 2011, 35, 530-536. [CrossRef]

70. Kawabata, S.I.; Nagayama, R.; Hirata, M.; Shigenaga, T.; Agarwala, K.L.; Saito, T.; Cho, J.; Nakajima, H.; Takagi, T.; Iwanaga, S. Tachycitin, a Small Granular Component in Horseshoe Crab Hemocytes is an Antimicrobial Protein with Chitin-Binding Activity. J. Biochem. 1996, 120, 1253-1260. [CrossRef] [PubMed]

71. Bachere, E.; Destoumieux, D.; Bulet, P. Penaeidins, antimicrobial peptides of shrimp: A comparison with other effectors of innate immunity. Aquaculture 2000, 19, 71-88. [CrossRef]

72. Munoz, M.; Vandenbulcke, F.; Saulnier, D.; Bachere, E. Expression and distribution of penaeidin antimicrobial peptides are regulated by haemocyte reactions in microbial challenged shrimp. Eur. J. Biochem. 2002, 269, 2678-2689. [CrossRef]

73. Li, C.Y.; Yan, H.Y.; Son, Y.L. Tiger shrimp (Penaeus monodon) penaeidin possesses cytokine features to promote integrin-mediated granulocyte and semi-granulocyte adhesion. Fish Shellfish Immunol. 2010, 28, 1-9. [CrossRef] [PubMed]

74. Song, Y.L.; Li, C.Y. Shrimp immune system-special focus on penaeidin. J. Mar. Sci. Technol. 2014, $22,1-8$.

75. Sotelo-Mundo, R.R.; Islas-Osuna, M.A.; De-la-Re-Vega, E.; Hernández-López, J.; Vargas-Albores, F.; Yepiz-Plascencia, G. cDNA cloning of the lysozyme of the white shrimp Penaeus vannamei. Fish Shellfish Immunol. 2003, 15, 325-331. [CrossRef]

76. Xing, Y.; Feng-Ying, G.; Qing-Mei, Z.; Jun-Jie, B.; Huan, W.; Hai-Hua, L.; Qing, J. Cloning and characterization of the tiger shrimp lysozyme. Mol. Biol. Rep. 2009, 36, 1239-1246. [CrossRef] [PubMed]

77. Liu, J.X.; Zhou, N.; Fu, R.; Cao, D.; Si, Y.; Li, A.; Zhao, H.; Zhang, Q.; Yu, H. The polymorphism of chicken-type lysozyme gene in Japanese flounder (Paralichthys olivaceus) and its association with resistance/susceptibility to List. Anguillarum. Fish Shellfish Immunol. 2017, 66, 43-49. [CrossRef]

78. Mai, W.; Wang, W. Protection of blue shrimp (Litopenaeus stylirostris) against the White Spot Syndrome Virus (WSSV) when injected with shrimp lysozyme. Fish Shellfish Immunol. 2010, 28, 727-733. [CrossRef] 